\title{
Água de beber: a filtração doméstica e a difusão do filtro de água em São Paulo
}

\author{
Julio Cesar Bellingieri \\ Curso de Administração e Sistemas de Informação da \\ Faculdade de Educação São Luís (Jaboticabal-SP) e \\ Faculdades Integradas Fafibe (Bebedouro-SP)
}

RESUMO: Este artigo trata do processo de surgimento e difusão do uso do filtro de água no Estado de São Paulo, ao longo do século XX. $\bigcirc$ filtro de água, conjunto de dois recipientes de argila equipado com vela filtrante, é um produto da indústria cerâmica, uma das primeiras a se desenvolver em São Paulo. A pesquisa mostra que, em São Paulo, no final do século XIX e início do XX, com o aumento da urbanização e o crescimento das cidades, a preocupação com a qualidade da água que se consumia ganhou importância em virtude de graves problemas de saúde pública principalmente epidemias causadas por águas impróprias para beber. Embora já existisse um incipiente mercado de equipamentos domésticos de filtração da água, eles eram ainda importados e de uso restrito. A partir da década de 1910, empresas cerâmicas, de imigrantes portugueses e italianos, passaram a acoplar velas filtrantes a recipientes de argila, dando origem ao filtro de água. Depois dos anos de 1930, o filtro difundiu-se e tornou-se o principal equipamento de filtração doméstica, quando diversas empresas, como Filtros Salus (São Paulo-SP), Pozzani (Jundiaí-SP) e Stéfani Uaboticabal-SP), especializaram-se nesse produto e passaram a atender ao mercado nacional. Estudar o surgimento e a difusão do filtro de água significa conhecer um dos primeiros bens de consumo da indústria brasileira e, ao mesmo tempo, a história de como a população obtém água para beber.

PALAVRAS-ChAVE: Água de beber. Saúde pública. Filtro de água. Indústria cerâmica.

ABSTRACT: This work studies the advent and diffusion of water filter usage in São Paulo State, during the 20th Century. The water filter, a set of two terracotta vessels equipped with a filtering device, was a product of the ceramics industry, one of the first to be developed in São Paulo. This research shows that in São Paulo at the end of 19th and beginning of 20th Centuries, with the growth of cities and rapid urbanisation, a concern about the quality of water increased due to serious public health hazards, mainly epidemics caused by the consumption of unhealthy 
drinking water. Despite the existence of an incipient market of domestic equipment for water filtration, these were imported and of limited usage. From the 1910's, ceramics companies, owned by Portuguese and Italian immigrants, started installing filtering devices in terracotta vessels, launching the water filter set. It caught on and became the main domestic filtering equipment after the 1930's, when several companies specialized in this kind of product and started catering for the national market, such as Filtros Salus (from São Paulo city), Pozzani (Jundiaí) and Stéfani Uaboticaball). Studying the advent and diffusion of the water filter entails knowledge about one of the first consumer goods of the Brazilian industry and, at the same time, knowledge about the history of the ways in which the Brazilian population obtained water to drink.

KEYWORDS: Drinking Water. Public Health. Water Filter. Ceramics Industry.

objetivo deste artigo é estudar as causas do surgimento e da difusão do uso do filtro de água, um dos primeiros produtos criados pela indústria nacional que, ao longo dos anos, tornou-se de uso generalizado na sociedade brasileira.

No Brasil, até o final do século XIX, não existia uma preocupação sistemática com a qualidade da água que se bebia nas residências. No Estado de São Paulo, principalmente no interior, a obtenção de água para beber davase por meio da ida a rios e riachos, poços ao lado das residências e manutenção de cisternas. Nas cidades maiores, incluindo a capital, São Paulo, a água para beber era obtida em bicas e chafarizes espalhados pela cidade.

A partir dos últimos anos do século XIX e princípios do XX, com o crescimento das cidades e o aumento do índice de urbanização, começaram a surgir diversos equipamentos e utensílios domésticos que tentavam filtrar e tornar potável a água que se consumia.

Em São Paulo, os chamados filtros de barro ou filtros de água (recipientes de cerâmica equipados com velas filtrantes) ganharam a aceitação dos consumidores e tornaram-se o equipamento para filtragem doméstica mais utilizado pela população. Ao longo das décadas, com a instalação de empresas de filtros de água nas diversas regiões do Brasil, o produto difundiu-se por todo o país, tornando-se um bem de consumo presente na maioria das residências brasileiras.

Não existem estudos sobre a história e a evolução do uso do filtro de água, tampouco sobre as empresas de cerâmica produtoras de filtros, embora esse produto remonte aos princípios da industrialização de São Paulo. Mesmo nos trabalhos que tratam do nascimento e da evolução da indústria de cerâmica no Brasil, e nos que estudam empresas de cerâmica, privilegiam-se os setores de louça/porcelana e de cerâmica de revestimento (pisos e azulejos). Sobre o surgimento e o desenvolvimento da indústria cerâmica brasileira, uma das poucas obras de referência é a de Pileggi (1958), embora seu estudo se encerre na década de 1950.

Este artigo divide-se em duas seções. A primeira tentou, de forma breve, resgatar as maneiras pelas quais a população paulista obtinha água para consumo doméstico e para beber, desde os primeiros colonizadores até o início do século XX, momento em que surgiu o filtro de água. 
A segunda seção buscou identificar quais foram os primeiros equipamentos domésticos de filtragem de água utilizados pela população, para, em seguida, tratar da invenção do filtro de água, analisando as condições que propiciaram a sua criação e difusão, no princípio do século XX. Procurou-se entender o contexto econômico e social desse período, contexto esse caracterizado pela imigração européia, pela grande incidência de epidemias e doenças na população paulista, pelo início dos serviços de tratamento e abastecimento público de água na maioria das cidades, pelo aumento dos índices de urbanização e pela expansão dos mercados consumidores paulistas.

Tentou-se responder às seguintes perguntas. Quando surgiram e quais foram as primeiras empresas fabricantes de filtros de água? Quais as técnicas e processos de produção utilizados nos primeiros filtros? Como e por que o uso do filtro se difundiu e se generalizou no Brasil, ao longo do século XX?

Para identificar as mudanças nas maneiras de se obter água potável para consumo doméstico, as fontes impressas são bastante escassas e esparsas. Neste artigo, recorreu-se a fontes secundárias, como publicações que descreviam a vida cotidiana dos habitantes de cidades paulistas. Foram também consultados almanaques, livros de exposições industriais e publicações que continham propagandas de empresas cerâmicas, na tentativa de identificar os primeiros e os principais fabricantes de filtros de água em São Paulo. Nesse caso, a tarefa foi bastante árdua, uma vez que são pouquíssimos os registros de empresas desse tipo. Na investigação sobre as matérias-primas e os processos de produção dos primeiros filtros, recorreu-se basicamente a entrevistas com antigos proprietários e trabalhadores de empresas cerâmicas.

Alguns conceitos serão utilizados ao longo de todo o artigo, e a sua definição objetiva se faz necessária para a compreensão do trabalho.

Define-se a cerâmica como qualquer material inorgânico, não-metálico, obtido geralmente após tratamento térmico em temperaturas elevadas. São várias as matérias-primas das quais se podem produzir artigos cerâmicos. A principal delas é a argila, definida como um material natural, terroso e fino que, ao ser misturado com água, adquire certa plasticidade, tornando-se fácil de ser moldado. Depois de moldado, o objeto é seco e, em seguida, cozido em alta temperatura, resultando no produto acabado. Em função de sua composição mineralógica, as argilas recebem diferentes designações: caulins, bentonitas, argilas refratárias, etc. (ANUÁRIO BRASILEIRO DE CERẤMICA, 2002).

Definiu-se aqui o filtro de água como um conjunto de dois recipientes de cerâmica, equipado com uma ou mais velas filtrantes e dotado de uma torneira no recipiente inferior. A vela é uma peça oca e cilíndrica, feita de material poroso, cuja função é reter partículas e bactérias presentes na água. Embora o elemento responsável por filtrar a água seja, obviamente, apenas a vela, é comum designar o filtro como todo o conjunto (recipientes cerâmicos + velas + torneira + tampa). Assim, chama-se de vela o elemento filtrante, e de filtro de água, os recipientes de cerâmica equipados com velas.

O filtro de água é um filtro de gravidade; a água a ser filtrada passa através da vela e goteja do recipiente superior para o inferior onde fica 
armazenada. A talha é um recipiente feito de argila, cuja utilidade é armazenar a água para beber, mantendo-a numa temperatura fresca, não tendo, portanto, a função de filtrá-la.

O abastecimento público e o consumo doméstico de água em São Paulo

A obtenção de água limpa para beber sempre foi um problema para as populações de todo o mundo. Sérgio Buarque de Holanda, em Caminhos e fronteiras, descreve as maneiras de se obter água potável, nos primórdios da ocupação do território paulista pelos bandeirantes. De acordo com o autor, no traçado das estradas e no estabelecimento das povoações, o problema da água tinha uma importância primordial. Viajantes estrangeiros, como Saint-Hilaire, ressaltaram a preferência dos povoadores do centro do Brasil pelas baixadas e fundos de vales; "a presença de boas águas determinou muitas vezes a escolha de sítios para instalação de povoados" (HOLANDA, 1994, p. 41).

$\mathrm{Na}$ ausência de rios, ribeirões e cursos de água, os exploradores pioneiros das terras paulistas tinham de matar a sede de outras formas; uma delas era consumindo plantas e vegetais capazes de preservar a água das chuvas dentro de si (no tronco, nos talos, nas raízes ou entre as folhas). Algumas dessas plantas, que Holanda chamou de "poços vegetais", eram a raiz do umbuzeiro, alguns tipos de cipós e os caraguatás (HOLANDA, 1994).

Holanda afirma ainda que não havia uma tradição de se fabricar cisternas ou poços artificiais para uso permanente; esses eram perfurados apenas para atender a necessidades momentâneas dos viajantes e, uma vez utilizados, ficavam sem qualquer proteção, embora, "em sítios não muito distantes dos povoados e junto aos pousos e registos, existiam, já em princípios do século XIX, aguadas sofrivelmente protegidas, onde se poderia obter água fresca" (HOLANDA, 1994, p. 42).

A análise da potabilidade da água que se bebia era feita empiricamente por meio da simples observação dos indivíduos, que separavam as consideradas "boas águas" das "águas pestilentas". A observação limitava-se aos aspectos visíveis e ao gosto da água. Se não se pudesse ver impurezas na água, se ela tivesse aparência cristalina e não tivesse gosto ruim, então devia ser própria para o consumo.

Ainda segundo Holanda, no fim do século XVIII, nos "lugares mais adiantados", já havia o costume de se quinar as águas transportadas durante as expedições e levá-las em grandes cabaças ou borrachas de couro (HOLANDA, 1994, p. 42). Essa prática foi, talvez, a primeira tentativa de se dar um tratamento à água consumida nos sertões de São Paulo.

O quinina é um alcalóide extraído da casca da quina, planta originária do Peru, com propriedades antitérmicas e antimaláricas. É capaz de reduzir o $\mathrm{pH}$ da água, tornando "águas poluídas" (com pH elevado) mais próprias para o consumo. 
Mesmo quando a população paulista passou a fixar-se em núcleos urbanos mais estáveis, não se eliminaram os problemas da escassez de água potável, da dificuldade em obtê-la e da sua qualidade precária. Nas cidades, inclusive na capital, as águas utilizadas pela população provinham de rios e ribeirões e também de poços artificiais e cisternas.

Taunay, no seu detalhado estudo sobre a vida na cidade de São Paulo, nos períodos colonial e imperial, descreve uma típica casa paulistana dos meados do XVIII: "a sala de visitas ocupando toda a frente da habitação, as alcovas, a camarinha, a cosinha e a dispensa [sic], os horriveis cubiculos dos escravos, o quintal exiguo com o indefectivel e contaminavel poço" (TAUNAY, 1949, p. 1091.

Na cidade de São Paulo, uma das primeiras referências sobre abastecimento de água potável data de 1744, quando os frades franciscanos construíram dutos para canalizar água do Rio Anhangabaú para o seu convento. Pensando nas sobras de água, solicitaram auxílio financeiro à Câmara Municipal para construírem um chafariz, do lado de fora do convento, que serviria à população. Esse chafariz público seria feito de cantaria com bicas de canos de bronze e duas pias (TAUNAY, 1949)'.

Já o primeiro grande chafariz da cidade foi instalado em 1792, no Largo da Misericórdia; tinha quatro torneiras, era abastecido com as águas do velho Córrego das Almas e, de acordo com Bruno (1954a, p. 285), "a sua construção parece ter exigido esforço enorme das autoridades, pois desde 1784 recebia a Câmara recursos para sua edificação e esbarrava com dificuldades inclusive para escolha das águas com que devia ser abastecido".

Com o aumento do número de habitantes, o problema da falta de água na cidade de São Paulo se agravava, no final do século XVIII e durante quase todo o XIX. Ernani Silva Bruno fornece uma descrição reveladora da situação do abastecimento nesse período.

Tão irregular quanto o abastecimento de gêneros da povoação de São Paulo em seus tempos coloniais - ou talvez mais irregular, pois a situação era ainda muito pouco satisfatória no primeiro quartel do século dezenove - foi o seu abastecimento de água. Nos primeiros tempos abasteciam-se os habitantes de Piratininga da água dos ribeirões e daquela que brotava de algumas fontes naturais, que aliás logo se tornaram locais imundos, sempre desafiando os propósitos de limpeza revelados através de medidas do poder municipal. A partir de meados dos setecentismo, por meio de alguns condutos de derivação, de que tiveram as primeiras iniciativas os religiosos do convento de São Francisco e dos recolhimentos de Santa Teresa e da Luz. Depois de fins do setecentismo, em chafarizes dos quais o mais importante e duradouro foi o da Misericórdia. Mas chafarizes que em geral se desmantelavam à toa e onde não raro faltava água, obrigando uma parte considerável da população a se utilizar do líquido sujo colhido no Anhangabaú e no Tamanduateí (BRUNO, 1954a, p. 278).

Freitas analisa os locais onde os habitantes de São Paulo matavam a sede, no ano de 1822: Chafariz da Misericórdia, nascentes naturais do Guaçu, do Miguel Carlos e do Moringuinho e cisternas. E, "quando tais fontes de abastecimento minguavam pelas prolongadas secas, recorriam às promessas à
1.A questão do abastecimento de água em São Paulo não é aprofundada neste artigo. Ernani Silva Bruno e Affonso de Escragnolle Taunay, ao analisarem as atas da Câmara da Cidade de São Paulo, obtiveram abundantes e interessantes informações sobre o assunto. Para uma breve história do abastecimento de água em São Paulo, incluindo a utilização de chafarizes e de serviços de aguadeiros pela população, veja a obra de Bruno (1954a, p. 278-290), período de 1554 a 1828; (1954b, p. 625-668), período de 1828 a 1872; (1954c, p. 1105-1128), período de 1872 a 1918. 
Nossa Senhora da Penha e aos rios que circundavam a cidade" (FREITAS, 1955, p. 101).

Questões relacionadas a problemas no abastecimento de água eram recorrentes nas reuniões da Câmara de Vereadores de São Paulo. Em 1823, discutia-se o fato de estar obstruído o cano condutor das sobras do Chafariz da Misericórdia para o quintal do Colégio e para o Palácio da Presidência, o que impedia a expedição das águas. Em 1824, numa sessão da Câmara, tratou-se da necessidade do desentupimento do Chafariz do Piques. Ainda, juízes de paz denunciavam a ação de uma mulher, que havia fechado um encanamento de água por ele atravessar os terrenos de sua chácara (TAUNAY, 1956b).

Em 1830, numa sessão da Câmara, o procurador do conselho declarou que o Chafariz da Misericórdia, perfeitamente reparado, vertia água em abundância, mas "convinha porém obstar que bois, cavalos e muares fôssem beber no tanque onde estava o açude represador das águas abastecedoras da principal fonte pública da cidade" (TAUNAY, 1956b, p. 444).

O avançar do século XIX não trouxe melhorias no abastecimento de água da capital paulista, apesar da construção de novos chafarizes e de caixasd'água, pelo poder municipal (BRUNO, 1954b). Em 1867, o jornal Diário de São Paulo reclamava do descaso do governo provincial para com a falta de água:

Sr. Tavares Bastos [presidente da Província], a Província de São Paulo não é um feudo de V. Exa. e dos seus turiferários. V. Exa. tem o direito de mandar os paulistas morrerem no Paraguai a ferro e fogo, mas não pode matá-los a sêde.. [...] Não temos água? Esperai, logo há de chover, e chover muito [...] (FREITAS, 1955, p. 101-102).

A dificuldade e a precariedade na obtenção de água geraram, ao longo do tempo, um sistema alternativo de distribuição, feito pelos chamados "aguadeiros" que, com carroças e pipas d'água, se serviam de água nos chafarizes e as vendiam em domicílio.

Os aguadeiros, no momento de venderem a água, deixavam um barrilzinho debaixo da torneira da carroça e enquanto ele se enchia lentamente, despejavam outro no interior da casa - traçando a carvão na parede, cada dia, um risco por vazilha fornecida, para cobrança no fim do mês (BRUNO, 1954c, p. 1121 ).

Se a simples obtenção de água pelos paulistas já constituía, por si só, um sério desafio, a precária qualidade da água agravava ainda mais o problema, uma vez que não havia qualquer tipo de tratamento mais sofisticado. As primeiras análises químicas, de cunho científico, das águas na cidade de São Paulo foram feitas em 1791, pelo astrônomo Bento Sanches d'Orta, que analisou 12 fontes. A água do Ribeirão do lpiranga não servia para se beber, por estar impregnada de "gás mefítico" (com cheiro podre e fétido). A Fonte do Gaia era péssima, sua água seria capaz de produzir muitas moléstias graves; a do Guaçu, localizada na Ladeira de Santa Ifigênia, era ruim como a do Gaia, embora menos férrea. A água do Rio Tamanduateí, muito pouco férrea, era 
ácida, com base de terra argilosa e vegetal, constituindo uma mistura lodosa pesada, tendo má cor e mau gosto; de acordo com o analisador, para se beber, seu uso não seria muito pernicioso, mas, para a lavagem e branqueamento dos tecidos de linho e algodão, ela não servia. Havia algumas águas ótimas para o consumo, como a de Santa Luzia, a da Fonte do Piques e as das fontes de São Francisco (TAUNAY, 1956a).

A água que saía dos chafarizes apresentava sujeiras, tendo passado por encanamentos deficientes, feitos em condições impróprias de nivelamento. Em 1833, as atas da Câmara Municipal de São Paulo registraram solicitação para que o fiscal informasse qual o motivo de aparecerem imundícies no Chafariz do Piques (BRUNO, 1954b, p. 653). A água vendida pelos aguadeiros era também retirada dos chafarizes e dos rios, o que levou um jornal de 1866 a escrever o seguinte:

É verdade que por aí rolam pipas soberbas que se propõem matar nossa sêde, todavia, apesar dessa virtude evangélica que tanto as honra por fora, por dentro nada são senão o Tamanduaté, com a diferença de ser a dinheiro e mais prejudicial à saúde, porque passa pelo lôdo e pelas imundícies intestinas das pipas... (FREITAS apud BRUNO, 1954b, p. 667).

Taunay publicou as impressões do paulistano Vieira Bueno que bem ilustram a deficiência na quantidade e na qualidade do abastecimento de água, em meados do século XIX:

No centro da parte principal da cidade havia somente o chafariz do Largo da Misericórdia, com quatro bicas, que nem sempre corriam abundantemente. Dia e noite estava ele, pois, rodeado de gente, na maior parte escravos, cujo vozerio se ouvia já de longe, quando por ali se passava. À noite, a concorrência se tornava maior, porque era aumentada pela pobreza recolhida. Quando em tempo de seca, o fornecimento escasseava, havia tamina e muitas vezes luta, em que se quebrava muito pote de barro, que era então a vasilha mais geralmente usada para condução de água. Santo Deus! hoje que não posso beber água que não tenha passado por um filtro Chamberlain Pasteur, arrepiam-se-me os cabelos quando me lembro da impureza da água do chafariz da Misericórdia, que era a que se gastava em nossa casa. Vinha do tanque chamado Reuno, que era uma represa dum pequeno córrego afluente do Anhangabaú; e em seu trajeto até chegar na cidade passava por um rego, descoberto, parte do qual atravessava um arrabalde escuso, chamado Rua do Rego, cujo ar era empesteado, e cujo chão era juncado de caveiras de boi, de sabugos, de chifres, de ossos, e de outros resíduos imundos, porque os moradores eram quitandeiros de miudezas do matadouro. Tem tudo aquilo natural explicação, não só na falta de recursos da Edilidade, como na inconsciente desídia, que havia então, geralmente, neste ramo do serviço público (TAUNAY, 1977, p. 326).

Durante as últimas décadas do século XIX, o sistema de abastecimento de água em São Paulo passou por grandes mudanças (BRUNO, 1954c). Em 1878, por meio de uma concessão do governo da Província, foi criada a Companhia Cantareira de Águas e Esgoto, uma empresa privada nacional, cuja função seria abastecer de água a cidade e construir a rede de esgotos. A água era captada na Serra da Cantareira e canalizada para o reservatório localizado 
2.Segundo Hoyos (2003), desde épocas pré-colombianas na América, alguns índios do continente usavam"filtros" primitivos feitos de pedra porosa e la va vulcânica, para separar os elementos sólidos da água que retiravam de poços, rios ou lagos.

3. Já no século XVI, os índios forneciam aos brancos objetos que sabiam manufaturar, tais como potes e igaçabas para água; em 1800, louças fabricadas pelos bugres figuravam na Feira de Pilatos, na cidade de São Paulo (BRUNO, 1966). Ainda segundo depoimento do viajante sueco Gustavo Beyer, em 1813, "nos arrabaldes [da cidade de São Paulo] moram crioulos ín dios, que fabricam potes de barro de grande consumo, porque é uso geral preparar neles a comida e carregar água" (BRUNO, 1981, p. 24). na Consolação; o projeto foi desenvolvido por engenheiros ingleses. Em 1887, a empresa já tinha conectado cinco mil imóveis à rede de água.

No entanto, o ritmo de crescimento da população da cidade era muito maior do que o da expansão dos serviços da Companhia Cantareira. Dessa forma, por não estar cumprindo seus compromissos, em 1892 o recéminstalado governo republicano encampou a companhia e, em 1893, criou a Repartição de Águas e Esgotos, órgão ligado à Secretaria da Agricultura, Comércio e Obras Públicas do Estado de São Paulo (SÃO PAULO, 1999).

Nos últimos anos do século XIX e início do XX, a rede de abastecimento de água ampliou-se consideravelmente. Em 1898, foi construído um novo reservatório na Consolação; em 1907, entrou em funcionamento o reservatório do Araçá e, em 1909, o do Belenzinho. Todavia, continuaram a existir graves deficiências no abastecimento (BRUNO, 1954c).

As origens da filtração doméstica de água:

a invenção e a difusão do filtro de água em São Paulo

Em todos os lugares do mundo, independentemente da existência de serviços públicos de abastecimento de água (bicas, chafarizes ou redes de encanamentol, as populações sempre possuíram costumes, técnicas ou equipamentos para tentar, domesticamente, tornar mais limpa a água que consumiam².

Assim, dada a qualidade precária da água que chegava aos paulistas, surge a seguinte questão: quais eram, no âmbito doméstico, os costumes e práticas que a população utilizava para tentar purificar a água consumida? A população detinha alguma técnica para livrar a água de impurezas, de modo a torná-la própria para beber?

Para responder a essas perguntas, é importante antes mencionar a maneira pela qual a população armazenava, nas residências, água para beber.

Desde o princípio da colonização portuguesa em São Paulo, eram os índios que manufaturavam e forneciam aos brancos os utensílios domésticos para guardar água, tais como potes, cuias e moringas, fabricados de argila ${ }^{3}$.

O uso desses utensílios incorporou-se por completo à cultura paulista. Nas descrições sobre a vida cotidiana dos habitantes de São Paulo, ao longo dos séculos, encontram-se muitas referências à utilização de objetos cerâmicos como recipientes de água. A respeito das residências da cidade de São Paulo e do seu mobiliário, na segunda metade do século XVIII, Taunay revela que, em um canto das salas de jantar, encontrava-se a moringueira, "onde nas quartinhas vinham uns e outros beber aos goles" (TAUNAY, 1951, p. 199-200). No seu estudo sobre as moradias paulistas anteriores à chegada do café, Lemos (1999) confirma que nas casas existiam moringas e potes, de que as famílias se serviam quando queriam beber água fresca. 
Os imigrantes europeus, chegados ao Brasil a partir do final do século XIX, também possuíam o costume de utilizar utensílios cerâmicos para armazenamento e transporte de água, bem como detinham as técnicas para a produção desses objetos. Foram portugueses e italianos que fundaram um grande número de empresas cerâmicas no Estado de São Paulo, especializadas na fabricação de talhas, moringas, potes, etc. Com isso, o novo tipo de economia e de sociedade que se formou a partir da imigração e da expansão cafeeira, manteve, e mesmo impulsionou, o uso de utensílios cerâmicos como meio de se servir de água nas residências. (Figura 1)

A talha de cerâmica foi o primeiro "equipamento" utilizado para purificar a água no âmbito doméstico, embora o processo de purificação fosse o mais rudimentar possível: a decantação. A água era simplesmente colocada dentro do recipiente e ficava "descansando" para que as impurezas sólidas se depositassem no fundo pela gravidade. Assim, a água "limpa" poderia ser retirada por cima com uma cuia ou concha. Outra prática utilizada pela população, embora menos comum, era ferver a água antes de bebê-la ${ }^{4}$.

Em São Paulo, a partir dos últimos anos do século XIX e princípio do século XX, começaram a surgir, em livros, almanaques e jornais, várias referências a aparelhos e equipamentos de filtragem e purificação de água para consumo doméstico. Algumas publicações e propagandas ressaltavam os filtros Berkfeld e Chamberland, como os mais indicados para a higienização domiciliar de água.

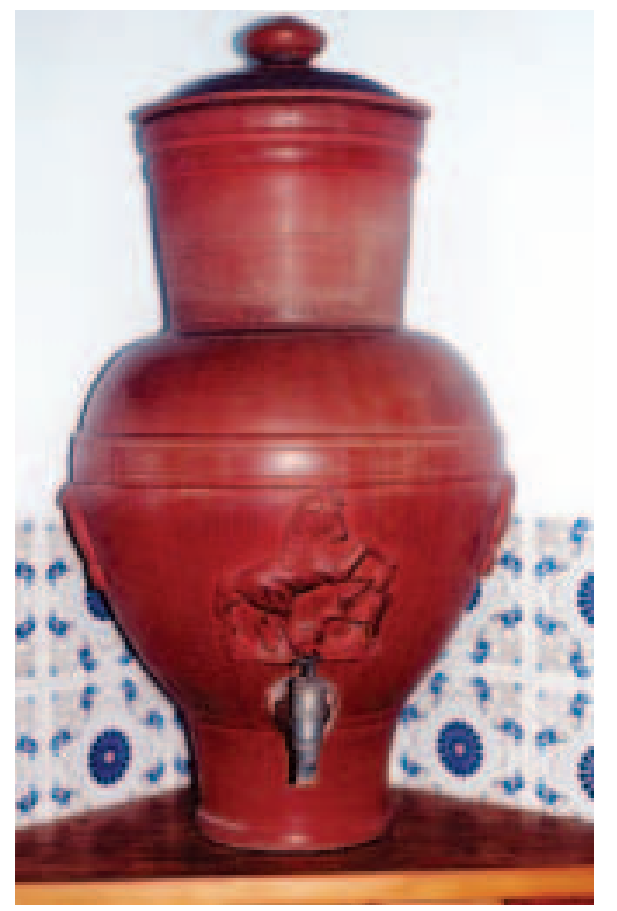

Figura 1 - Talha de cerâmica com torneira de chumbo fabricada no início do século XX, por empresa desconhecida. Acervo pessoal de Márcio Augelli, São Paulo-SP, 2003. 
Esses filtros eram velas ocas de porcelana porosa, inventadas e produzidas na Inglaterra e conhecidas em várias partes do mundo.

Por exemplo, Afrânio Peixoto, em seu livro Elementos de Hijiene, de

1913 , dedica espaço à questão da "filtração domiciliária":

Existe uma enorme quantidade de filtros preconizados pela industria ou pelo uso, para a filtração das aguas, ordinariamente complemento da filtração central. São mais ou menos imperfeitos, e algumas vezes ilusorios: tais os chamados filtros, de pedra porosa ou barro cozido, usados geralmente no Brasil.

Se um filtro domiciliar é necessario, não ha para aconselhar outros que os de terra de infusorios: vela Berkfeld ou de porcelana porosa: vela Chamberland. O filtro Berkfeld, usado na Alemanha, produz a filtração de 2 litros d'agua por minuto; a depuração d'agua deixa porem a desejar. O filtro Chamberland, tambem chamado Pasteur, é mais seguro, embora mais lento: 4 litros por hora e por vela. Para aumentar a quantidade de liquido filtrado recorre-se às baterias de filtros, montadas as velas convenientemente.

[...] A agua é absolutamente pura de germens se todavia a vela não oferece falha ou solução de continuidade [...], e é frequentemente esterilizada em solução antiseptica [...], em agua fervendo, ou melhor, no fôrno.

Porque senão, ao cabo de alguns dias de funcionamento a materia organica obtura os poros externamente o que diminue o fluxo da filtração ou os microbios conseguem passar até o interior. Sem estes cuidados repetidos frequentemente, a filtração, mesmo a melhor, é ilusoria (PEIXOTO, 1913, p. 73-74) (Figura 2).

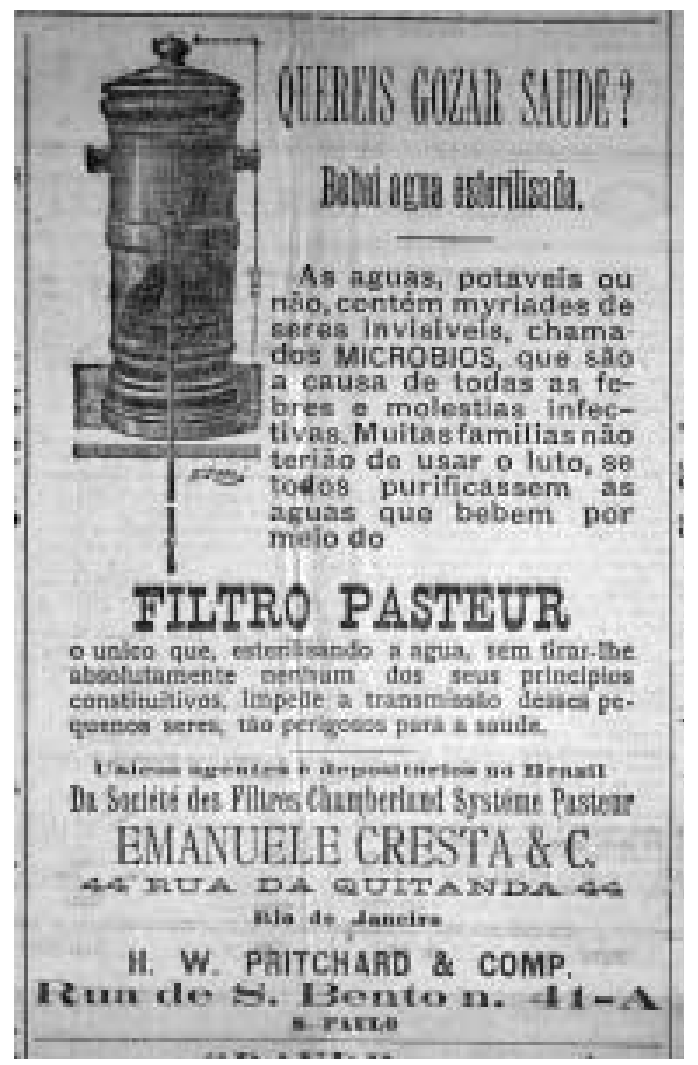

Figura 2 - Propaganda do Filtro Pasteur, publicada num jornal (não identificado) de São Paulo, provavelmente da década de 1910 ou 1920. A referência aos representantes comerciais mostra que se tratava de um produto importado. Arquivo pessoal da Profa. Dra. Maria Alice Rosa Ribeiro, 2003. 
A seguir, a descrição do funcionamento do filtro de Chamberland:

É bastante conhecido o filtro de porcelana porosa, dito de Chamberland, que se aplica largamente como filtro doméstico, para purificar a água de beber. No modêlo sem pressão, a vela mergulha-se na água, contida em vaso cilíndrico de vidro ou loiça; a água filtra de fora para dentro, ganha o interior da vela, que é ôco, e escoa-se finalmente por um orifício, numa das extremidades. No modêlo sob pressão (v. figura) a vela de porcelana A está dentro de uma manga metálica $D$ fixada à torneira da água. Vela e manga unem-se hermeticamente em C. Quando se abre a torneira, a água enche o espaço anular E e, sob a influência da pressão, filtra através a parede da vela, de fora para dentro, saindo finalmente pelo orifício B. Uma vela dá cerca de 30 litros de água filtrada por dia. Estas velas devem limpar-se, ou melhor, regenerar-se uma a duas vezes por semana (GRANDE ENCICLOPÉDIA..., 1953, p. 394) (Figura 3).

No começo do século XX, muitas residências brasileiras possuíam esses tipos de filtros instalados no ponto de entrada de água da casa. Nota-se que, embora o elemento filtrante fosse de porcelana, o recipiente em que este ficava era feito de metal. Muitas vezes, o elemento filtrante era chamado de vela de porcelana, pois a sua matéria-prima (caulim, filito, etc.) era a mesma da fabricação de porcelana de mesa (pratos, tigelas, xícaras), embora o processo de produção fosse diferente ${ }^{5}$.

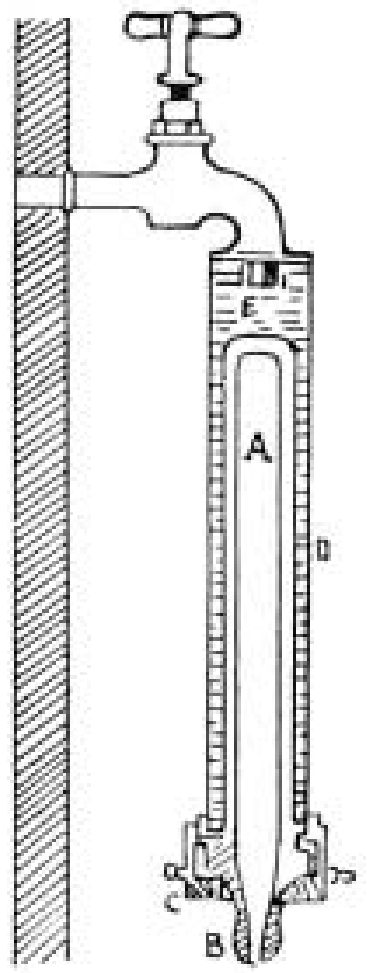

Figura 3 - Representação da parte interna do Filtro Chamberland. IGRANDE ENCICLOPÉDIA, 1953, p. 394). 
6. Entrevistas com Victor Lamparelli Júnior e Rubens De Stéfani.

7.Dados de importações, publicados em:SÃO PAU LO, 1921, 1922, 1923 , 1927. Os entrevistados foram unânimes em afirmar que esses equipamentos existiam em pouquíssimas residências nas primeiras décadas do século XX (entrevistas com João Gonçalves Pito,Victor Lamparelli Júnior, Aparecido Paiva, Rubens De Stéfani e Alexandre Alves Bessa)
Outro equipamento utilizado para purificar a água era uma espécie de "pedra filtrante", mecanismo composto de uma armação de ferro de 1,2 metro, apoiando uma pedra porosa de $10 \mathrm{~cm}$ de espessura e de cerca de 50 quilos, em formato de cuba. Jogava-se água sobre a pedra que, depois de absorvida, pingava filtrada dentro de uma talha de argila, localizada na parte de baixo da armação (Figuras 4 e 5).

De acordo com a investigação realizada, esse "filtro de pedra", utilizado durante as primeiras décadas do século XX em algumas residências de municípios paulistas e de outros Estados, era francês e chegava ao Brasil por meio de um importador do Rio de Janeiro, chamado Eduardo L. da Silva Ribeiró.

Esses equipamentos filtrantes, tais como o Filtro Pasteur e o filtro de pedra, não tinham o uso generalizado, e suas importações deveriam ser pouco significativas. Na descrição dos produtos importados pelo Brasil, por meio do Porto de Santos, na década de 1920, não existe menção a esses objetos. No entanto, o aumento das suas referências demonstra que havia uma crescente preocupação com a qualidade da água que era bebida. Os livros e publicações tratando da "filtração doméstica" e as propagandas de equipamentos filtrantes significam a existência de um incipiente mercado relacionado à purificação de água para beber em São Paulo.

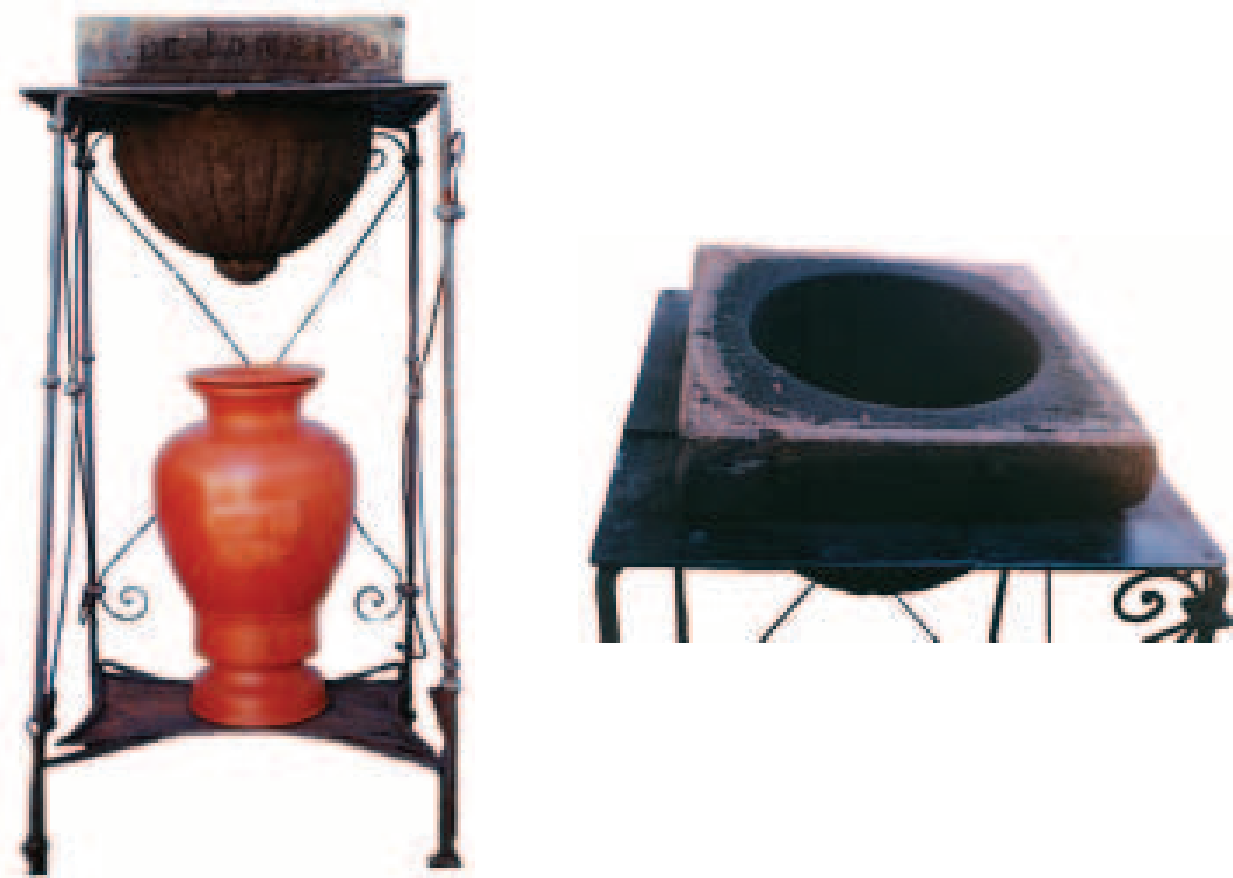

Figuras 4 e 5 - Filtro de pedra original, sob dois ângulos diferentes. A talha situada abaixo do filtro é uma réplica, fabricada pela Cerâmica Stéfani (Uaboticabal-SP). Acervo da Paróquia de Nossa Senhora de Lourdes, Jaboticabal-SP, 2003. 
As primeiras referências à fabricação no Brasil de filtros domésticos surgiram a partir do ínicio do século XX, mas de maneira escassa e esparsa. Ainda não eram, entretanto, filtros de argila. A primeira referência encontrada está num catálogo da Exposição Nacional de 1908, o qual descreve as empresas expositoras. No 45 grupo, o de fabricantes de artigos de cobre e outros metais comuns, lê-se: "Dias Martins - Piracicaba - 2 filtros, sendo um de folhas de flandres e outro de madeira, denominados (Filtros do Agricultor'" (EXPOSIÇ̃̃O NACIONAL DE 1908..., 1908, p. 85).

No Almanak Laemmert (1913, p. 4479), na parte destinada ao comércio, indústria e profissões da cidade de São Paulo, há uma "empresa" fabricante de filtros, de Ernesto de Castro \& Cia, na Rua Boa Vista, 26. Porém, não foi possível saber de que material o recipiente era feito, mas supõe-se que não era de argila, pois a empresa não era do setor cerâmico, haja vista que estava ausente nas categorias cerâmicas e louças de barro, descritas no mesmo almanaque. No Almanak Laemmert para 1915 e 1916, desapareceram as referências a filtros.

Entretanto, rapidamente algumas empresas de cerâmica passaram a equipar com elementos filtrantes (velas) as talhas que produziam. Embora a talha tivesse a vantagem de manter a água fresca para o consumo, não tinha a função de filtrá-la. A partir do momento em que se acoplou um elemento filtrante a um recipiente de argila (talha), alterou-se radicalmente a função deste último, que incorporou uma nova e importante utilidade, a capacidade de transformar água imprópria para o consumo em água potável.

Na talha, a água era retirada pela abertura superior do recipiente. Com a incorporação de um elemento filtrante, foi necessário dividir a talha em dois recipientes. Jogava-se a água a ser filtrada pela abertura superior do recipiente de cima e então ela passava pela vela e pingava, já filtrada, para o recipiente inferior, ao qual foi preciso acoplar-se uma torneira para extraíla.

Por isso, é possível adotar a expressão "invenção" do filtro de água. Pois, apesar de o princípio do processo de fabricação de elementos filtrantes já ser conhecido em outros países e de o uso da talha cerâmica como recipiente de água ser uma prática que remonta ao início da civilização humana, esses dois elementos só agora passariam a ser combinados, dando origem a um novo produto. Um produto que filtra a água e a mantém fresca para o consumo, dentro da própria residência.

Uma das primeiras empresas fabricantes de filtros que, seguramente, eram feitos de argila, foi a Companhia Cerâmica Villa Prudente, localizada na capital e fundada em 1910 por um grupo de industriais e engenheiros paulistas, tendo como seu presidente Francisco de Paula Ramos de Azevedo. Tratava-se de uma das mais importantes cerâmicas do Estado, durante as primeiras décadas do século XX, e estava dividida em três seções, produzindo uma linha bastante 
8. CINQUANT'ANNI, 1937 , p. 418

9. EXPOSIÇÃO, 1908 , p. 58-59. diversificada de produtos, como telhas, tijolos, ladrilhos, azulejos, pratos e tigelas de louça vidrada.

A secção de terra-cotta artística e louça de barro comprehende variadissima fabricação de 'cachepots', jarras, vasos, ornatos architectonicos, entre os quaes convém mencionar os azulejos pintados para decorações e barras interiores e exteriores, e os mais variados typos e estylos de talhas, filtros, copos e moringues (MANNING, 1919, p. 525).

A Cerâmica Villa Prudente foi adquirida, em 1922, pelo imigrante italiano Giuseppe Zappi, que, sabendo da "qualidade promissora" das jazidas de argila e caulim da empresa, resolveu imediatamente direcioná-la para a fabricação de artigos sanitários 8 . A empresa, assim, deixou de fabricar louças de barro e, por conseqüência, filtros de água.

O melhor exemplo da transição da fabricação de talhas em direção à fabricação de filtros, por parte de algumas empresas paulistas, é o da Adelino Ferreira \& Irmão, a chamada Cerâmica Paulista, fundada em 1893 pelo imigrante português Joaquim Ferreira. Na Exposição Nacional de 1908, no Rio de Janeiro, a empresa pertencia ao grupo de cerâmica e ladrilhos hidráulicos e produzia "moringues, vasos, talhas e outros objectos de barro" filtros.

Já no começo da década de 1920, de acordo com um texto publicitário em Lapri ([1922?]), a empresa fabricava "todos os artigos de ceramica propriamente ditas e especialmente filtros, talhas e moringues para agua: jarros e cache-pots de terra-cotta para pintura, vasos para jardins, etc. etc." (Figura 6).

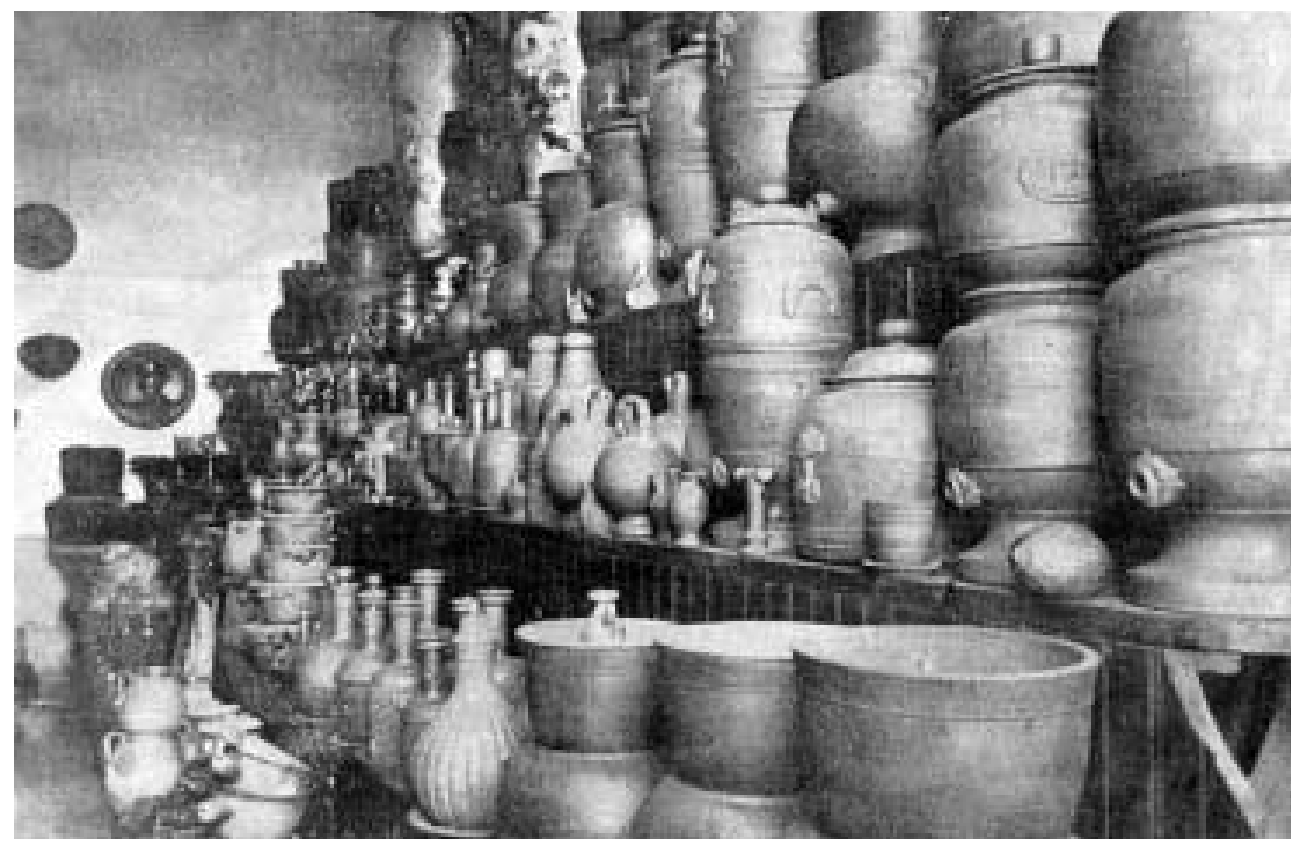

Figura 6 - Filtros em estoque na Cerâmica Paulista: no canto superior direito, vários filtros, sem a torneira; mais abaixo, algumas talhas. (LAPRI, [1922?]). 
Em 1928, de acordo com a Estatística industrial do Estado de São Paulo, existiam duas empresas da capital que produziam talhas, moringas, vasos e filtros. Eram elas a Cerâmica Paulista (de F. Ferreira \& Cia, antiga Adelino Ferreira \& Irmão), com 50 operários, e a Cerâmica Bom Retiro (de Botelho \& Oliveira), com 17 operários (SÃO PAULO, 1930/1939).

Em 1929, a Estatística industrial citava três fabricantes de filtros: os dois do ano anterior e mais a R. Macedo \& Irmãos, também da capital paulista. Entretanto, a partir do ano seguinte, desapareceu da estatística a classificação de fabricantes de filtros; as empresas citadas acima passaram a constar como louças de barro. Apenas em 1937 constou novamente uma empresa produtora de filtros, a Antonio Nogueira \& Cia.

Quando pode ser considerada a data da invenção do filtro de água, e qual foi a empresa pioneira na fabricação desse produto?

Em São Paulo, desde o século XIX, existia um sem-número de fábricas de louças de barro, espalhadas por todo o Estado, que produzia diversos tipos de talhas, potes e moringas para o acondicionamento doméstico de água. Foram alguns dos seus proprietários, imigrantes portugueses ou italianos, que, tendo noção do processo de fabricação de elementos filtrantes, passaram a produzir talhas munidas desses equipamentos, ou seja, filtros. Como a grande maioria, essas empresas eram pequenas, de caráter artesanal, provavelmente não participavam de exposições industriais nem apareciam em almanaques, estatísticas e publicações que traziam informações sobre empresas diversas.

Além disso, as próprias informações dos almanaques e publicações da época eram irregulares e esparsas; a Estatística industrial, conforme os próprios organizadores advertiam, não era coletada de modo rigoroso: muitas empresas ficavam de fora e outras fabricavam produtos que não eram citados.

Daí a dificuldade em se determinar quando exatamente se iniciaram a produção e a comercialização de filtros de água (de argila) e qual a primeira empresa a atuar nesse mercado em São Paulo. O que pode ser afirmado é que algumas empresas já produziam filtros de água na região, desde a década de 1910.

Como eram fabricados e do que eram compostos os elementos filtrantes que as empresas produziam, durante as primeiras décadas do século XX? Cabe distinguir dois tipos. $\bigcirc$ primeiro, mais rudimentar, era poroso, em formato de bolacha ou disco e ficava colado entre os dois recipientes de argila. Em geral, era uma massa composta de argila, areia fina e carvão que era levada ao forno para a queima e, em seguida, colada no fundo do recipiente superior do filtro. Esse tipo de elemento filtrante produzia uma filtragem muito lenta, gotejante.

A Cerâmica Lamparelli, localizada em Jaboticabal-SP, produzia esse tipo de elemento filtrante desde 1920 e deu o nome de filtro reto ao produto que levava esse disco, feito de um composto de argila, carvão e outros componentes e pregado com uma mistura de breu e cera, para que a água não vazasse. Na parte de baixo do filtro, era colocada uma torneira de chumbo, para extrair-se a água ${ }^{10}$. 
11. Este é o chamado processo de colagem (barbotina). Atualmente, as velas são fabricadas por prensagem (a massa cerâmica que compõe a vela é prensada por máquinas). Entrevistas com Aparecido Paiva, Rubens De Stéfani e Luiz Carlos Businaro Ferreira.

12. SÃO PAULO, 1923, $\mathrm{p}$ 173. Esse empresário recebeu também uma menção honrosa pela fabricação de ingredientes para lustrar móveis e limpar metais. segundo tipo de elemento filtrante era a vela propriamente dita. Em geral, era composta de uma mistura de caulim e filito. No seu processo de fabricação, os minerais passavam por uma pequena moagem, para reduzir o tamanho dos seus grãos. Em seguida, adicionando-se água aos minerais, era formada uma massa líquida. Essa massa era colocada em uma fôrma de gesso que, ao ser girada, absorvia a água da massa enquanto esta se aderia à fôrma, adquirindo o formato de vela. Assim, a massa, já no seu formato final, era retirada do molde e cozida (queimada) no forno" ". Pronta, a vela adquiria permeabilidade, o que permitia a passagem da água e retenção das impurezas presentes no líquido. A vela ficava fixa dentro do recipiente superior do filtro.

Pelo fato das matérias-primas utilizadas na fabricação dos elementos filtrantes serem minerais, eles eram usualmente chamados de minerais e não de velas.

As empresas cerâmicas tentavam desenvolver suas próprias fórmulas para as velas por meio de pesquisas e experimentos geralmente realizados pelos seus proprietários. A criação de uma nova fórmula ou uma nova combinação de componentes era tratada com absoluto segredo. Portanto, os componentes da vela e seu processo produtivo não seguiam um padrão único, variando de empresa para empresa.

Com o tempo, as cerâmicas foram aperfeiçoando as velas, tornando-as de melhor qualidade e mais baratas, de forma que passaram a tomar o lugar dos outros elementos filtrantes. Como exemplo, pode-se citar a própria Cerâmica Lamparelli: entre os anos de 1926 e 1928, o seu proprietário desenvolveu uma fórmula própria de vela, lançando, a partir daí, o Filtro São João, que passou a substituir o filtro reto nas vendas da empresa.

A primeira referência documental encontrada, relativa à fabricação de velas filtrantes, está na relação dos premiados do Estado de São Paulo da Exposição Internacional do Centenário da Independência do Brasil, em 1922: Octavio Teixeira Mendes, de Piracicaba, recebeu uma medalha pela sua fabricação de filtros e velas ${ }^{12}$. Na Estatística industrial do Estado de São Paulo para 1929, essa mesma empresa voltou a aparecer como produtora de velas, possuindo 10 operários.

Urbanização, saúde pública e filtros de água

Quais foram as causas que possibilitaram, no Estado de São Paulo, o aparecimento das talhas de argila munidas com velas filtrantes e a posterior difusão do seu uso pela população? Quais fatores fizeram o filtro de água tornarse o principal equipamento de filtração doméstica em São Paulo?

Para responder a essas perguntas, deve-se levar em conta o processo de mudança pelo qual passou o Estado de São Paulo, no princípio do século $X X$. Esse processo, provocado pela economia cafeeira, trouxe as condições para a emergência do uso do filtro de água como um produto de consumo, que seria crescentemente utilizado pelas populações paulistas. 
Essas condições podem, assim, ser enumeradas: a) a imigração européia que trouxe indivíduos conhecedores das técnicas de produção cerâmica e capazes de aproveitar de forma inovadora a existência, em território paulista, de vários tipos de argila; b) o aumento da urbanização e o crescimento das cidades, ocorridos em função da expansão e da diversificação das atividades industriais e comerciais, que inviabilizaram por completo as maneiras antigas de se obter água potável (poços, rios, chafarizes) e, ao mesmo tempo, agravaram os problemas sanitários, nas cidades e nos campos, trazendo à tona, como questão prioritária, a importância de se consumir água potável.

Em primeiro lugar, como condição necessária para o surgimento do filtro de argila, deve-se considerar a imigração européia, especificamente a de portugueses e italianos, que conheciam a técnica da fabricação de velas filtrantes, já existentes em seus países de origem.

Alguns imigrantes aproveitaram-se da ampla disponibilidade de argila nos locais onde se instalaram, e da qual já se fabricavam talhas, potes, moringas, para acoplar as velas às talhas de argila, criando o novo produto. Até a década de 1930, todas as empresas produtoras de filtros de água no Estado, identificadas nesta pesquisa, eram de propriedade de imigrantes ou de filhos de imigrantes portugueses ou italianos. Sem a presença deles, não seria possível o surgimento desse produto ainda no começo do século XX'13.

Em segundo lugar, deve-se compreender o contexto econômico e social do Estado de São Paulo, nos princípios do século XX. $\bigcirc$ processo de crescimento das cidades e o aumento da urbanização de muitos municípios, causados pela dinamização da economia cafeeira, inviabilizavam cada vez mais as práticas antigas e precárias de obtenção de água para beber, como ir a um rio, córrego, abrir um poço no quintal da residência ou, em cidades maiores, deslocar-se até uma fonte ou chafariz.

Além disso, os desdobramentos no âmbito industrial, comercial, demográfico e urbano da economia cafeeira produziram um grave e duradouro fenômeno: problemas de saúde pública nas cidades e nos campos paulistas. $\bigcirc$ rápido crescimento de muitas cidades e o aumento da população nas fazendas e áreas rurais, sem a correspondente criação de uma boa infra-estrutura de saneamento básico (redes de água, esgoto e coleta de lixo), geraram um grande número de doenças e epidemias, que assolaram o Estado, nos fins do século XIX e início do XX'14.

No interior, entre 1889 e 1904, os deslocamentos das massas de trabalhadores imigrantes para as regiões cafeeiras em expansão foram acompanhados por epidemias de febre amarela. Ao mesmo tempo, as precárias condições sanitárias e de higiene dos habitantes das zonas rurais e fazendas abriram caminho para muitas endemias, como a ancilostomíase (amarelão ou opilação), malária, tracoma e mal de Chagas. Na capital, o crescimento repentino e desordenado provocava epidemias de febre tifóide, tuberculose, cólera e uma alta mortalidade infantil. A causa da maioria das epidemias e moléstias estava diretamente relacionada ao consumo de água polvída (RIBEIRO, 1993).
13. Não foi possível concluir se recipientes de argila equipados com velas filtrantes eram fabricados em Portugal ou na Itália e se os imigrantes ceramistas trouxeram de seus países a idéia da fabricação desse produto. As entrevistas realizadas levam ao argumento de que o filtro, tal como definido neste artigo, foi criado no Brasil. Se existissem filtros de água em uso, naqueles países, provavelmente alguns teriam sido importados; porém não há registros ou relatos do uso desses filtros no Brasil.Todavia, em relação a Portugal, a Associação Portuguesa de Indústria Cerâmica (mediante consulta por email,em 14/2/2003) informou, de modo vago, que "filtros de água" eram utilizados em Portugal, mas não se conhecem as empresas nem os períodos em que poderiam ter sido produzidos.

14. Para uma análise da evolução da saúde pública no Estado de São Paulo e das relações da imigração e urbanização com o aumento das epidemias e dos problemas sanitários, entre 1880 e 1930 , Ribeiro (1993). 
A seguir, um curioso artigo publicado em um jornal (não identificado) da capital, em 12 de junho de 1896, que bem ilustra a situação da saúde pública em São Paulo.

EPIDEMIOLOGIA - Como se evita a febre amarella com um livrinho de 200 réis.

No dia 9 do corrente, entrou no consultorio do dr. Bittencourt Rodrigues um homem de nacionalidade portugueza, ainda moço, de olhar intelligente, para pedir conselhos sobre ligeiros incommodos que sofria.

Estando a hora um pouco adeantada e pedindo-the o dr. Bittencourt que voltasse no dia seguinte, retorquiu elle:

- Sou empregado em uma fazenda em Araraquara e preciso absolutamente voltar para lá amanhã, sem falta.

- Para Araraquara!? - ponderou o dr. Bittencourt - não tem medo da febre amarella?

- Não, senhor, sou portuguez, e portuguez não apanha febre amarella. [...]

- Como assim?! O que é que faz o meu amigo para evitar a febre amarella?

- Portuguez só bebe agua fervida. Somos 70 portugueses, que estamos na fazenda Passos Manoel, em Araraquara, há 13 mezes, e nem um só de nós ainda cahiu doente. Todas as madrugadas, o nosso primeiro cuidado é pôr no fogo um grande caldeirão de agua para ferver. Fervida a agua, cada um dos meus homens toma a sua ração para o dia. Ninguem bebe de outra agua na fazenda. [...]

- Não ha na fazenda outros colonos? Não ha lá italianos?

- Ah! Os italianos!... esses morrem como gallinhas...Ainda ha pouco, só em 5 dias morreram 16.

- Mas, como assim?! Porque é que os italianos morrem como gallinhas?!

Sacudindo a cabeça e com um mal disfarçado sorriso de ironia:

- Os italianos não bebem agua fervida!... [...]

- Mas, quem foi que aconselhou vocês a só beberem agua fervida?

- Antes de embarcarmos em Lisboa para cá, eu sabia que vinhamos para um paiz em que se morre como moscas e que era preciso tomar cuidado. Portanto, antes de arrumar a nossa bagagem a bordo, fui a uma livraria e comprei um livrinho de hygiene da Bibliotheca Util, de Portugal, que me custou 200 réis. Esse livrinho manda que: no tempo de epidemia só se beba agua fervida! É o que temos feito.

O dr. Bittencourt quasi succumbiu à emoção e, ainda hoje, não poude voltar do transbordamento de alegria que the causou esta scena commovente, surgindo deante do seu espirito o quadro da futura humanidade expurgando a terra de todos os flagellos e patenteando horisontes ainda não sonhados para a vida popular sob o governo da Sciencia! $[\ldots]$

Quantas centenas de vidas de brasileiros não teriam sido poupadas?! Quantas lagrimas, quantos despedaçamentos de coração, quantas angustias não se teriam evitado, se o livrinho de 200 réis acompanhasse o dote de todos os casamentos e servisse de archete a todos os paes, a todas as mães de família...e....a todas as autoridades sanitárias?!!! [...] São Paulo, 1 1-6-96 Dr L. P. BARRETTO.

Entre as últimas décadas do século XIX e as primeiras do XX, existia uma grande preocupação, por parte dos governantes, médicos e sanitaristas, 
para se conscientizar a população dos hábitos e práticas de higiene. Havia uma grande quantidade de livros, publicações, artigos em jornais e em periódicos que alertava para o estado precário das condições de vida no interior e tentava difundir a importância do saneamento e de noções de higiene, incluindo os cuidados com a qualidade da água (RIBEIRO, 1993).

Belisario Penna, em Saneamento do Brasil, primeira edição em 1918, atribui a inferioridade econômica e o atraso do Brasil ao estado de prostração e apatia da maioria dos trabalhadores do país, gerado por várias doenças, como malária, mal de Chagas e ancilostomíase. Para o autor, a solução dar-seia pelo completo saneamento do Brasil e pela educação higiênica, cujo principal aspecto seria ensinar a população a beber água limpa e protegida de insetos e parasitas causadores de moléstias transmissíveis. De acordo com Penna, embora nas capitais e cidades do interior já existissem canalizações de água potável e redes de esgotos, nada havia sido feito em relação às habitações rurais (PENNA, 1923, p. 1801.

Bertolli Filho (2003), ao estudar a ocorrência de uma grave epidemia de gripe na cidade de São Paulo (gripe espanhola), entre outubro e dezembro de 1918, constatou o seguinte fato: os anúncios de alguns produtos, publicados em jornais, adaptavam as "funções" da mercadoria às necessidades oriundas da situação epidêmica. Um dos exemplos foi o do chamado Filtro Fiel.

O anúncio veiculado antes do advento da gripe falava sobre a proximidade do verão e do conseqüente aumento de casos de doenças infecciosas, enquanto, pouco depois da constatação dos primeiros casos de influenza, o mesmo produto foi anunciado simplesmente invocando, logo no início do discurso, a [gripe] "hespanhola" (BERTOLLI FILHO, 2003, p. 132).

Assim, mesmo não sendo a água necessariamente uma transmissora do vírus, lá estava reforçada a necessidade de se beber água filtrada (Figura 7).

Os graves problemas de saúde pública, causados em boa parte pelas águas sujas e polvídas, não puderam ser eliminados ou minimizados com as redes públicas de abastecimento de água, surgidas já a partir do fim do século XIX e início do XX: além de as redes atenderem a poucos domicílios, a água encanada que chegava até as residências era alvo de um tratamento insuficiente para torná-la potável.

Eram comuns reclamações a respeito da má qualidade do líquido distribuído. Em Campinas, a Comissão Sanitária do município reclamava, em 1903, da escassez e da qualidade da água encanada fornecida à população. Na mesma época, a população de Ribeirão Preto utilizava correntemente cisternas, pois a água encanada não era suficiente para as duas zonas da cidade, a alta e a baixa. Na cidade de São Paulo, a taxa de mortalidade de crianças com até um ano era bastante elevada, sendo as causas das mortes geralmente problemas do aparelho digestivo (diarréias, enterites), ligados à má qualidade da água. Em 1914, alguns bairros de São Paulo foram atingidos por 


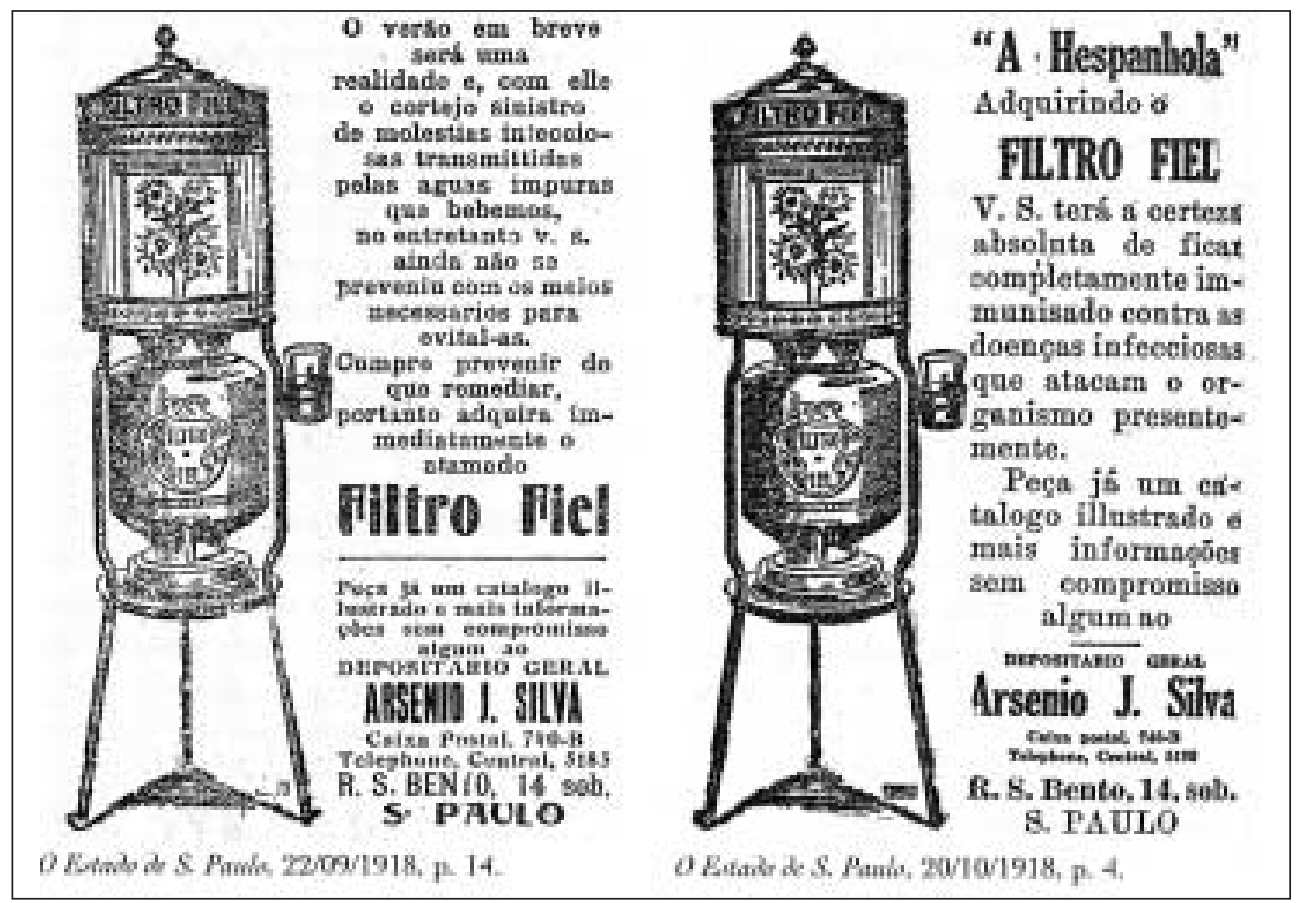

Figura 7 - Propagandas do Filtro Fiel, em São Paulo, 1918. (BERTOLLI FILHO, 2003, p. 132).

uma epidemia de febre tifóide, causada pela insalubridade das águas do Rio Tietê que abasteciam parte da cidade, mas que não recebiam nenhum tipo de tratamento (RIBEIRO, 1993).

Bertolli Filho dividiu a cidade de São Paulo em quatro grupos distritais e analisou os tipos de moradias e os serviços de infra-estrutura existentes em cada um deles, no início do século XX. Apenas o grupo distrital Central (Sé e Consolação), reunindo 10\% da população, possuía um serviço de abastecimento de água satisfatório. As águas que iam para essa região,

captadas nos mananciais da Serra da Cantareira, eram de qualidade bem superior às distribuídas em outras áreas da cidade, sendo normalmente classificadas, mediante análises laboratoriais, como "extremamente salubres" (BERTOLLI FILHO, 2003, p. 41).

No grupo distrital Intermediário (Liberdade, Bela Vista, Santa Ifigênia e Santa Cecília), abrangendo $31 \%$ da população e habitado principalmente por classes proletárias, os cortiços eram a forma de moradia mais comum, e o serviço de água, esgoto e coleta de lixo existia apenas nas ruas principais.

Nos grupos distritais Periférico (Bom Retiro, Brás, Mooca, Belenzinho) e Suburbano (Cambuci, Santana, Lapa, Penha, São Miguel, Nossa Senhora do Ó, Butantã e Vila Mariana), que somavam quase 60\% da população, os serviços de abastecimento de água, quando existiam, eram absolutamente precários. A água 
fornecida aos bairros periféricos era captada do Rio Tietê e, entre 1906 e 1908, 16 de 30 análises da água concluíram que ela não era potável.

Isto se devia não só ao fato de ser a água inconvenientemente tratada, mas também porque eram freqüentes as constatações de mal [sic] funcionamento da distribuição da água e da coleta de esgoto, permitindo o contato direto entre os dois sistemas (BARRETO apud BERTOLLI FILHO, 2003, p. 45).

Assim sendo, dada à imperfeição e precariedade dos serviços de abastecimento de água, criava-se uma situação em que as pessoas recebiam água dentro de suas próprias residências, mas sabiam que ela não era pura o bastante para ser bebida; sendo assim, era natural que as pessoas se preocupassem ou tivessem a necessidade de possuir equipamentos que fizessem o que as empresas fornecedoras não faziam, isto é, tornar a água potável para o consumo.

Deve-se lembrar que foi somente a partir de 1926 que as águas da rede pública da capital passaram a receber tratamento com cloro (CAMPOS, 2001) (Figuras 8 e 9).
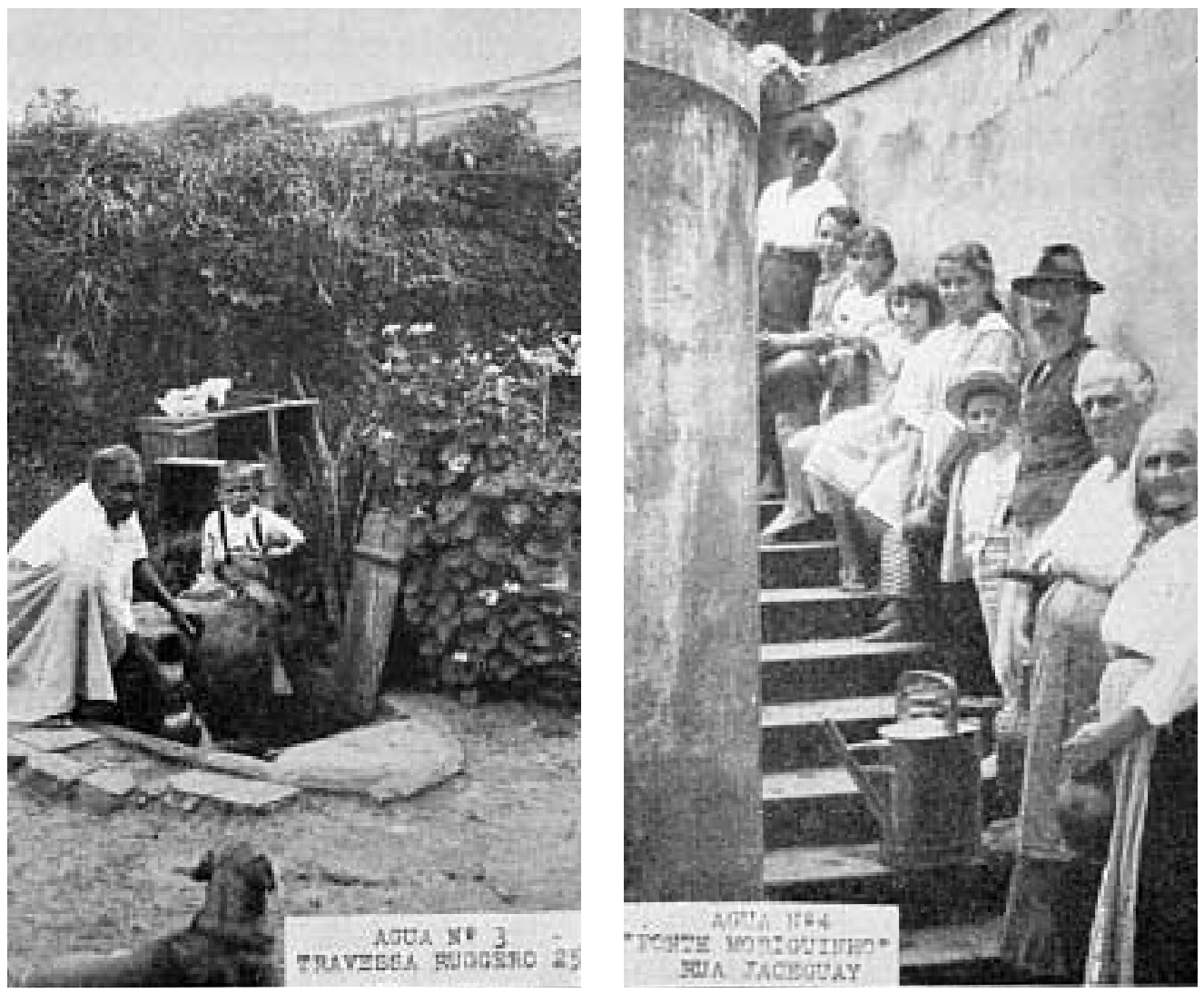

Figuras 8 e 9 - Abastecimento de água por bicas, em São Paulo, princípio do século XX. Arquivo pessoal da Profa Dra Maria Alice Rosa Ribeiro, 2003. 
Em suma, a crescente urbanização de algumas cidades, a precariedade dos serviços de abastecimento de água, as inúmeras doenças e moléstias que não perdoavam quem consumisse águas impuras e uma maior preocupação com a questão da higiene abriram caminho para o nascimento e o crescimento de um novo mercado, o de filtros de água.

Pelo lado da oferta de filtros, havia os imigrantes europeus que, em função do contexto descrito, aproveitaram-se da abundância de matérias-primas disponíveis e lançaram-se nesse novo ramo de atividade.

Pelo lado da demanda por filtros, pode-se dizer que já havia, em São Paulo, um conjunto de pessoas aptas e dispostas a comprar um equipamento para filtração doméstica, pois tentar tornar a água mais pura, mais que uma necessidade, poderia ser uma questão de sobrevivência.

Dado que a importação de equipamentos filtrantes (Filtro Pasteur, filtro de pedra porosa, etc.) era inacessível à grande maioria da população e deveria ser insignificante, o filtro de água foi a solução nacional encontrada para o desafio de tornar próprias para o consumo doméstico as poluídas águas brasileiras. Utilizando-se de matérias-primas e capitais nacionais, conseguiu-se desenvolver um produto substituto aos equipamentos filtrantes importados.

Os filtros de água, portanto, representaram um auxílio à saúde pública da época, levando o tratamento da água até as residências. Assim, tanto o homem da cidade como o do interior poderiam transformar águas insalubres em potáveis, sem dependerem dos precários serviços públicos e sem terem de recorrer a equipamentos de uso difícil e restrito.

\section{A difusão do filtro de água (1930-1980)}

A década de 1930 pode ser considerada como o início da generalização do consumo do filtro de água no Estado de São Paulo; a partir desse período, algumas empresas cerâmicas especializaram-se e concentraramse na fabricação de filtros e/ou velas filtrantes, passando a conquistar novos mercados para esse produto. $\bigcirc$ filtro de água deixava de ser uma novidade, uma inovação restrita a poucas residências, para tornar-se um produto importante dentre os que uma residência possuía.

É útil analisar, sucintamente, o caso de três das mais importantes empresas fabricantes de filtros, em São Paulo, que se especializaram na fabricação desse produto, na década de 1930: a Cerâmica Lamparelli, a Francisco Pozzani e a Antonio Nogueira \& Cia.

A Cerâmica Lamparelli foi fundada em 1920, em Jaboticabal, pelo imigrante italiano Victor Lamparelli. Tratava-se de uma empresa pequena e tipicamente familiar.

Por volta de 1926, depois de algum tempo de estudo e muitas experiências, Lamparelli conseguiu desenvolver um tipo de vela capaz de filtrar a água com mais eficiência do que o disco filtrante, presente no filtro reto. A empresa, então, acoplou essa vela a dois recipientes de argila e lançou o Filtro São João (entrevista com Victor Lamparelli Júnior). 
A vela era formada por um cilindro fechado, composto de uma mistura de caulim, carvão e outras substâncias, e parafusada com duas arruelas de borracha a uma chapa de ferro cromada, a qual, por sua vez, era pregada com cimento entre os dois reservatórios do filtro. A vela poderia ser desparafusada da chapa para limpezas regulares.

Filtro São João levava uma torneira de metal cromado pregada com breu e cera. Posteriormente, ela passou a ser parafusada com duas arruelas de borracha. O logotipo do filtro, com a inscrição São João, era moldado numa fôrma de gesso e depois pregado no reservatório superior do filtro. $\bigcirc$ produto tinha quatro tamanhos diferentes, identificados por números. $\bigcirc$ filtro número quatro, o maior, tinha 72 centímetros de altura e capacidade para cerca de 10 litros. (Figuras 10 e 11 )

processo de produção do filtro era essencialmente artesanal: o ceramista colocava um pedaço de argila limpa e tratada sobre um torno, moldando com as mãos os reservatórios do filtro. Em seguida, depois de secos, eles eram levados para um forno a lenha, onde seriam queimados a uma temperatura aproximada de $1.000^{\circ} \mathrm{C}$. Depois disso, os filtros eram pintados e recebiam as velas e a torneira.
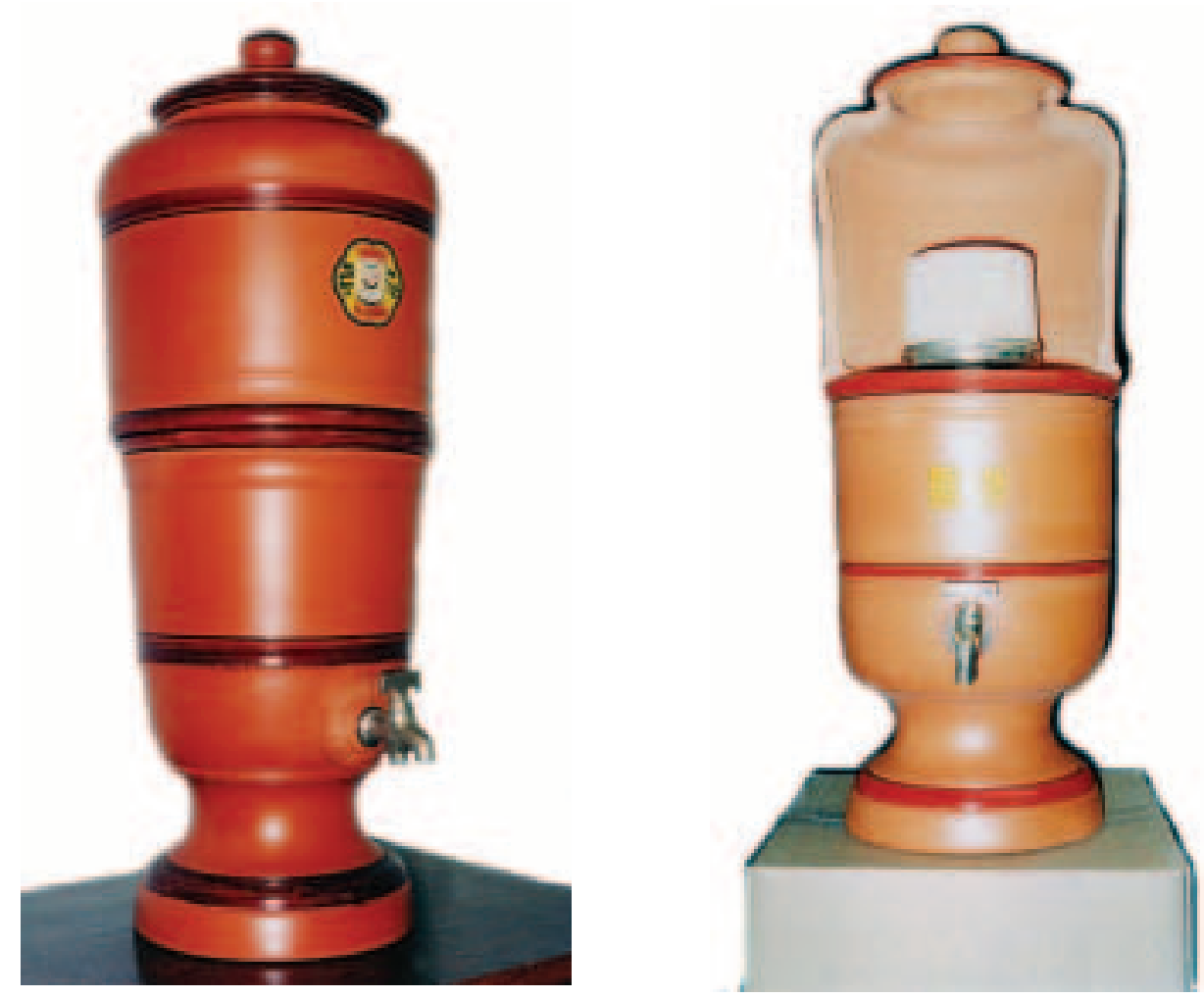

Figuras 10 e 11 - À esquerda, uma réplica do primeiro Filtro São João; à direita, uma réplica dos anos 1940, com o reservatório superior secionado para a visualização da vela filtrante. A vela filtrante e as torneiras são originais da época. Acervo da Cerâmica Stéfani, JaboticabalSP, 2003. 
período que vai de aproximadamente 1926 até o início dos anos 1940 foi o de maior expansão da Cerâmica Lamparelli. Com a aquisição de dois caminhões, em 1925 e em 1927, a empresa pôde buscar novos mercados em vários municípios da região. Até então, as entregas para outros municípios eram feitas por via ferroviária (Companhia Paulista de Estradas de Ferro), o que limitava o mercado às cidades atendidas pela ferrovia e gerava altos custos, em virtude de boa parte da produção quebrar durante a viagem de trem, por causa da fragilidade do material.

Em pouco tempo, o Filtro São João tornou-se o produto mais importante da empresa. De acordo com entrevista com Victor Lamparelli Júnior, por volta de 1929, o filtro foi destaque numa feira industrial na cidade de São Paulo, por sua vela ter sido capaz de filtrar (reter) o azul de metileno da água.

Os maiores mercados da empresa constituíam o chamado sertão de Rio Preto: Catanduva, Taquaritinga, Monte Alto, Guariba, Matão, Araraquara, Casa Branca, Avaré, Ribeirão Preto (todos em São Paulo) e também algumas cidades do Estado de Goiás e a região do Triângulo Mineiro. Assim sendo, pode-se considerar a Cerâmica Lamparelli como um dos marcos iniciais da difusão e disseminação do filtro de água no interior de São Paulo (Figura 12).

Em 1947, Victor Lamparelli vendeu sua cerâmica para quatro jovens irmãos da família Stéfani, os quais fundaram a Irmãos De Stéfani (depois Cerâmica

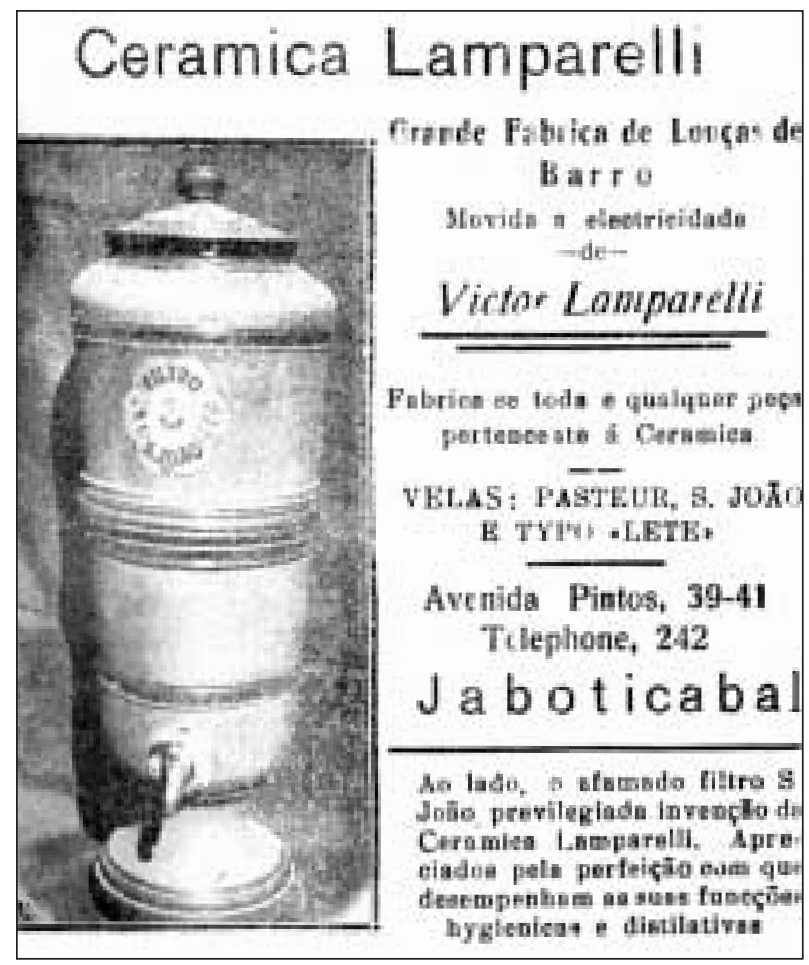

Figura 12 - Propaganda da Cerâmica Lamparelli. Diário de Jaboticabal, 5/1 1/1938. 
Stéfani S.A.), empresa que se tornou a maior fabricante de filtros do país, a partir das décadas de 1960 e 1970, tendo como produto líder o Filtro São João.

A empresa de Francisco Pozzani foi fundada em Jundiaí, em 1934, com o intuito de produzir velas filtrantes. Filho de um imigrante italiano, Pozzani trabalhava como fundidor de sanitários na Companhia Cerâmica Jundiaiense, em Jundiaí. Por volta de 1931, um de seus filhos foi acometido de tifo e, de acordo com as ordens médicas, necessitava beber água filtrada e fervida. Obteve, com muito custo, no almoxarifado da Companhia Paulista de Estradas de Ferro, um filtro italiano (de metal), de marca Lete.

Pozzani passou então a acreditar que seria capaz de fabricar um produto similar àquele. Começou a realizar muitos experimentos e testes para a fabricação de velas, num barracão de sua casa e nos fornos da Cerâmica Jundiaiense, com a autorização da direção da empresa. Em 1934, obteve do Serviço Sanitário do Estado de São Paulo a licença de fabricação e venda de velas para filtros, quando então montou, nos fundos de sua casa, uma empresa para fabricar esse produto (FILIPPINI, 2003).

A empresa apareceu pela primeira vez na Estatística industrial do Estado de São Paulo em 1936 com um capital de 40:000\$000, dois operários e produzindo unicamente velas para filtros. Em 1937, tinha um capital de 27:000\$000, ainda dois operários e fabricava velas de porcelana para filtros.

Na década de 1940, a empresa iniciou também a fabricação de objetos de porcelana de uso doméstico. Em 1953, já denominada Indústrias Francisco Pozzani S.A., possuía 380 funcionários e uma produção diária de 35.000 peças cerâmicas, comercializadas em todo o país (UMA INDÚSTRIA..., 1953).

A Antonio Nogueira \& Cia foi fundada em 1935, na capital, pelo imigrante português Antonio Nogueira, com o objetivo de produzir filtros de água. Com ele, vieram outros ceramistas, que produziam peças de cerâmica artesanalmente.

Na Estatística industrial de 1935, a empresa consta como instalada na Rua do Mercado Municipal, n. 5, com um capital de 150:000\$000, 30 operários e produzindo louças de barro simples e vidrado. Em 1936, já instalada na Vila Guilherme, tinha um capital de 300:000\$000, 27 operários e fabricava louças para uso doméstico, vasos, recipientes para laboratórios e outras peças para ornamentação. Em 1937, tinha um capital de 1.000:000\$000, 42 operários e produzia "talhas, moringas, filtros esterilizadores marca 'Salus', cerâmica artística em estilo Marajouara, etc." (SÃO PAULO, 1930/1939, p. 150).

Essa empresa trouxe uma importante inovação na filtragem doméstica da água, lançando o primeiro filtro esterilizante do mercado. A origem desse filtro merece alguns comentários.

Roberto Hottinger, médico veterinário suíço, naturalizado brasileiro e estabelecido em São Paulo, professor de Bioquímica da Escola Politécnica e proprietário de um laboratório de análises clínicas, desenvolveu, durante as décadas de 1910 e 1920, diversos estudos sobre a qualidade da água de abastecimento público da cidade de São Paulo. Tinha como assistente o 
15. GUIA, 1998, p. 695; entrevista comAlexandre Alves Bessa. farmacêutico e médico Geraldo Horácio de Paula Souza, que possuía também grande interesse por questões de higiene e saúde pública e exerceria, entre 1922 e 1927, a função de diretor do Serviço Sanitário do Estado de São Paulo (CAMPOS, 2001).

Além dos vários experimentos e artigos escritos a respeito da má qualidade das águas, principalmente as do Rio Tietê, os estudos desses dois cientistas também envolviam pesquisas com o uso de metais para a esterilização de água. Hottinger, com o auxílio de Paula Souza, desenvolveu um novo processo de purificação, que consistia em revestir de prata coloidal as partes internas de recipientes cerâmicos, o que eliminaria as bactérias presentes na água. Esse processo foi batizado de Salus.

Antonio Nogueira mantinha contatos com Hottinger, e a sua empresa passou a utilizar-se desse novo processo, que se tornou também a marca do filtro. Assim, além de eliminar as partículas da água, por meio da vela, o Filtro Salus também esterilizava a água ${ }^{15}$.

Nos primeiros anos de funcionamento, a empresa também fabricava os chamados filtros de parede, acoplados no registro de água das residências. Eram de metal e em vários tamanhos. Dentro do recipiente de metal, havia uma vela equipada com carvão ativado. Era possível abrir a vela, por meio de um bocal giratório, e retirar o carvão, que deveria ser trocado de tempos em tempos. Embora não tenha sido possível encontrar algum exemplar desse equipamento, acredita-se que era semelhante ao filtro inglês Chamberland. Também não se sabe por quanto tempo a empresa de Antonio Nogueira produziu esses filtros de parede.

Durante a década de 1940, essa empresa cresceu rapidamente, passando a empregar centenas de funcionários e diversificando sua linha de produtos, com filtros de vários tamanhos, moringas, talhas, vasos, enfeites de cerâmica, etc. Depois do falecimento de Antonio Nogueira, em 1956, a administração da empresa ficou a cargo do seu filho, Antonio Nogueira Filho (entrevista com Alexandre Alves Bessa).

Muitas outras cerâmicas especializaram-se em produzir filtros de água a partir da década de 1930. Não foi possível estimar com rigor o número exato, pois, na Estatística industrial, as empresas produtoras de filtros estavam inseridas na categoria genérica de louças de barro, a qual engloba filtros, talhas, boiões, potes, moringas, alguidares, assadeiras e vasos. Dessa forma, uma empresa assim classificada não necessariamente produzia filtros. Em 1928, havia no Estado nove empresas na categoria louça de barro; em 1930, havia 10; em 1932, 12; em 1934, 20 e em 1937, 19. Além disso, conforme já foi dito, muitas empresas fabricavam produtos que não eram mencionados pelas estatísticas.

No caso dos produtores de velas filtrantes, depois de Octavio Teixeira Mendes, de Piracicaba, o qual apareceu em 1929, passaram a constar a empresa de Romeu Ranzini (1931-1936) e as Indústrias Reunidas Francisco Matarazzo (1933-1936), ambas da capital, além de Francisco Pozzani, de Jundiaí (1936-1937). 
De 1931 em diante, a Estatística industrial publicou dados sobre valor e quantidades produzidas de velas de porcelana para filtros. Entre 1930 e 1934, passou a informar o valor da produção de talhas (embora as quantidades só em 1933 e 1934) e, entre 1935 e 1937, mencionava valores e quantidades de talhas com e sem filtro (vela). Isso mostra que o mercado para esse produto expandia-se e tornava-se relevante, pois já havia dados desagregados específicos.

Durante as décadas de 1930, 1940 e 1950, o filtro de água foi sendo incorporado ao rol das utilidades que as residências, escritórios, fábricas e outros estabelecimentos possuíam. Adquiriu-se o hábito de reservar ao filtro um lugar de destaque na cozinha das residências, geralmente sobre uma toalha, numa cantoneira ou prateleira, como se fosse um objeto artístico ou de decoração. Contribuía o fato de muitos filtros possuírem desenhos pintados à mão. Dado isso, pode-se sugerir que, pelo menos nesse período, ele trazia certo status às residências.

Embora inexistam informações sobre o preço do filtro de água, para aquela época, pode-se afirmar que ele inicialmente não era um produto relativamente barato. Comparando-se dados de quantidade produzida e valor de produção de alguns produtos, constantes na Estatística industrial entre 1935 e 1937, pôde-se ter uma idéia do valor relativo do filtro em relação a outros utensílios. Por exemplo, o preço de uma talha (com e sem filtro) representava a metade do preço de um aparelho de jantar completo. Isso pode justificar a idéia de que o filtro era caro. Além disso, como os dados se referem genericamente a talhas com e sem filtro, é certo que o filtro com vela era ainda relativamente mais caro.

Segundo entrevista com Victor Lamparelli Júnior, o Filtro São João era comprado por "indivíduos com renda mais alta". Se o público consumidor da Cerâmica Lamparelli fosse dividido em três classes de poder de compra, o São João era comprado pela classe alta; a classe média comprava uma talha com torneira ou um filtro reto; e a baixa, um pote ou moringa sem torneira (Figura 13).

Embora o enfoque deste artigo esteja no Estado de São Paulo, é válido fazer uma breve referência à Cerâmica Luso-Brasileira, localizada em Niterói-RJ, a qual possuía como principal produto o chamado Filtro Rei (COUTINHO, 1989). A sua existência reforça e ilustra a idéia de que o início da fabricação de filtros no Brasil deu-se por meio dos imigrantes europeus, sobretudo portugueses.

A empresa foi fundada em 1918, pelo português José Joaquim Fernandes. Depois da sua morte, em 1941, a propriedade da cerâmica foi transferida para o seu genro, Edgar Rei, que diversificou a linha de produtos fabricados e expandiu o mercado geográfico da empresa para outros Estados, além do Rio de Janeiro.

Dos objectos constantes do Catálogo formam um grupo importante os usados para provisão, purificação e serviço de água - filtros, moringas, potes e talhas -, que, fabricados já no tempo do sr. Fernandes, adquirem agora características mais modernas. A simples incorporação de uma vela de tipo Pasteur, produzida também na fábrica, na metade superior de um filtro permitia purificar em melhores condições a água nele introduzida. Considerado como corrente 
16. A Pesquisa Nacional por Amostra de Domicílios (PNAD), realizada pelo Instituto Brasileiro de Geografia e Estatística (IBGE), que inclui perguntas a respeito da existência de alguns bens duráveis nos domicílios, quantifica a evolução do uso de filtros de água nas residências do país. Em 1972 $29,3 \%$ dos domicílios brasileiros possuíam filtro; em 1981, o índice cresceu para $51,7 \%$; em 1990 , foi para $57,2 \%$ e, em 2002 caiu para $53,1 \%$. No Estado de São Paulo, em 1972 42,3\% dos domicílios tinham filtro, percentual que foi para $61,9 \% \mathrm{em}$ 1981, 65,4\% em 1990 e $54,2 \%$ em 2002.Tomandose cada região brasileira isoladamente, vê-se que ocorreu o mesmo: consolidação do uso do filtro na década de 1970 e aumento do percentual de residências com filtro, porém há taxas decrescentes, durante os anos de 1980, e declínio a partir de 1990 (PNAD, IBGE, diversos anos).

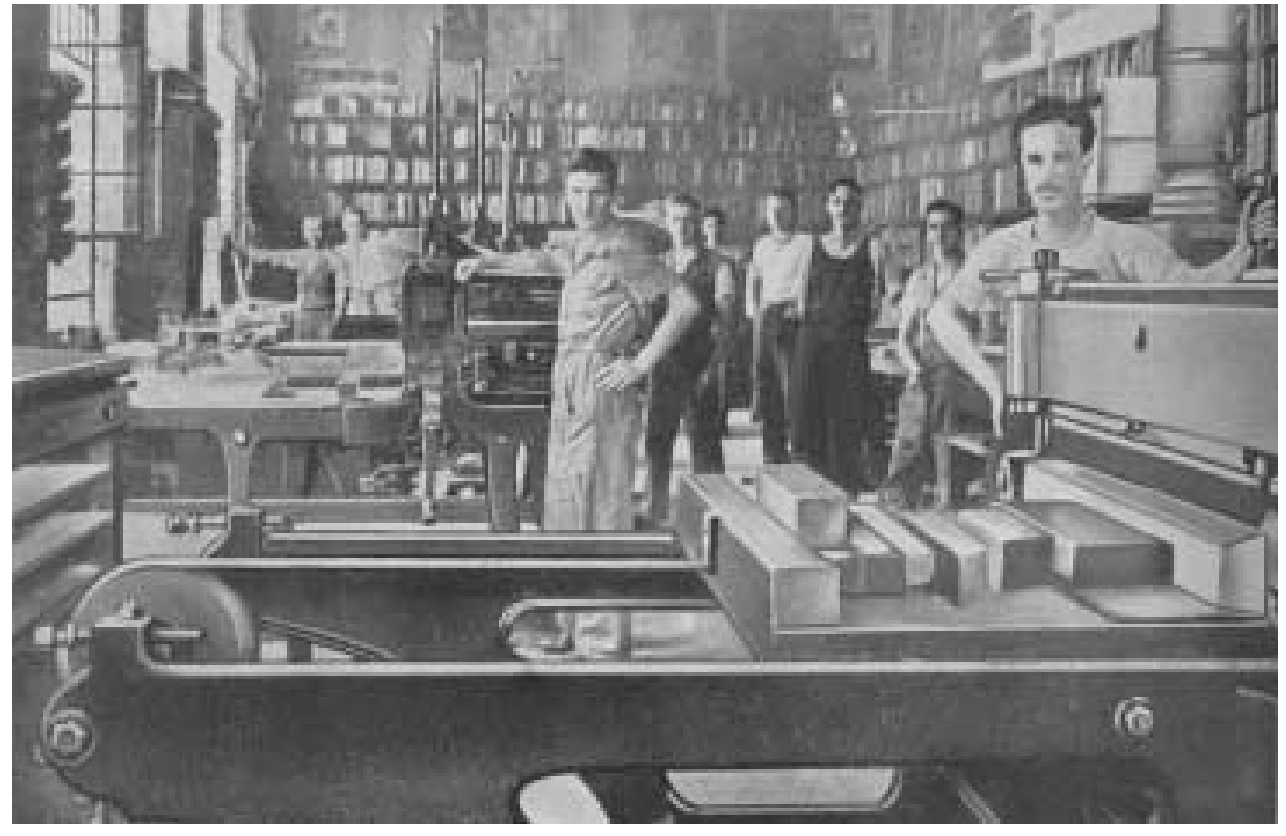

Figura 13 - Filtro de água em oficina de São Paulo, década de 1930. (CINQUANT'ANNI DI LAVORO, 1936, p. 498).

o filtro Rei, o modelo extra distingue-se por uma pasta mais fina, e o esterilizante por uma galba mais elaborada. Destinados à provisão há que considerar os potes e as talhas, das quais a talha Rei pode armazenar água já purificada desde que lhe seja adaptado, num tubo exterior de carga, um sistema de vela semelhante ao dos filtros. As moringas - "antigamente, - frigorífico dos pobres" -, cujas formas comum e Rei lembram as garrafas de água de presença obrigatória nas salas de jantar dos hotéis elegantes da belle époque, apresentam também uma modalidade esterilizante, por revestimento idêntico ao das saladeiras. Opções de escolha tão variada são ainda, de algum modo, o testemunho do arcaico prazer português de saborear água, pura e fresca [...] (COUTINHO, 1989, p. 21).

Durante as décadas de 1960 e 1970, sobretudo nesta última, o uso do filtro se generalizou mais rapidamente em todas as regiões brasileiras ${ }^{16}$. Diversas empresas aumentaram de tamanho, tanto em número de funcionários como em capacidade produtiva, dedicando-se à fabricação em massa de filtros e/ ou de velas, atendendo assim a mercados crescentes estadual e nacionalmente. Como exemplos, a própria Pozzani, a Filtros Salus e a Irmãos De Stéfani. $O$ filtro, um dos primeiros bens de consumo criados pela indústria nacional, tornouse, dessa forma, parte integrante da cultura e dos costumes brasileiros relacionados à obtenção de água para beber.

Para concluir, é interessante constatar que a água que chegava à maioria da população brasileira, pelos serviços de abastecimento público, já era de qualidade bastante superior à fornecida no princípio do século (melhor tratamento, adição de cloro, etc.), o que deveria desestimular aquisições de 
equipamentos filtrantes. No entanto, o avançar do século só fez difundir mais e mais o uso do filtro, o que demonstra que boa parte da população não confiava na qualidade e na potabilidade da água de abastecimento público.

Embora não tenha sido abordado neste artigo, vale mencionar que, a partir das décadas de 1980 e 1990, o uso do filtro entrou num processo de declínio: o surgimento de produtos substitutos, como os purificadores, amparados num marketing agressivo que exalta um modo tecnologicamente avançado de filtrar água, e a água mineral engarrafada, apoiada numa ampla e eficaz rede de distribuição, acabou por provocar mudanças nas necessidades e nos costumes dos consumidores, causando o início do processo de abandono do uso do filtro de água em muitas residências brasileiras (ver nota 16).

Finalmente, não se pode deixar de concluir que o estudo do surgimento e da difusão do filtro não deixa de ser um estudo da própria evolução dos costumes, hábitos e equipamentos pelos quais a população brasileira obtém água para beber. Desde os períodos colonial e imperial, quando a água vinha de poços e chafarizes, até o início do século XXI, quando aparelhos purificadores se encarregam de tornar a água potável, não tem fim o esforço dos indivíduos tentando purificar a água que bebem; nessa história, o filtro é apenas um desses equipamentos, o mais relevante deles.

\section{REFERÊNCIAS}

ALMANAK LAEMMERT $69^{\circ}$ ANNO: Estado de São Paulo. Rio de Janeiro: Officinas Typographicas do Almanak Laemmert, 1913.v. 3.

ALMANAK LAEMMERT $71^{\circ}$ ANNO: Estado de São Paulo. Rio de Janeiro: Officinas Typographicas do Almanak Laemmert, 1915. v. 3

ALMANAK LAEMMERT $72^{\circ}$ ANNO: Estado de São Paulo. Rio de Janeiro: Officinas Typographicas do Almanak Laemmert, 1916. v. 3

ANUÁRIO BRASILEIRO DE CERÂMICA. São Paulo: Associação Brasileira de Cerâmica, 2002.

BERTOLLI FILHO, C. A gripe espanbola em São Paulo, 1918: epidemia e sociedade. São Paulo: Paz e Terra, 2003.

BRUNO, E. S. História e tradições da cidade de São Paulo. 2. ed. Rio de Janeiro: José Olympio, 1954a.v 1., 1954b. v. 2, 1954 c v. 3.

Viagem ao país dos paulistas: ensaio sobre a ocupação da área vicentina e a formação de sua economia e de sua sociedade nos tempos coloniais. Rio de Janeiro: José Olympio, 1966.

Memória da cidade de São Paulo: depoimentos de moradores e visitantes, 1553-1958. São Paulo: PDPH, 1981 (Série Registros, 4). 
CAMPOS, C. de. A cidade através da bigiene, 1925-1945: As propostas de Geraldo Horácio de Paula Souza para São Paulo. 2001. Dissertação (Mestrado em Estruturas Ambientais Urbanas) Faculdade de Arquitetura e Urbanismo, Universidade de São Paulo, São Paulo, 2001.

CINQUANT'ANNI DI LAVORO degli italiani in Brasile: lo Stato di S. Paolo. São Paulo: Societá Editrice Italiana, 1936. v. 1., 1937.v. 2.

COUTINHO,A. P. Edgar Rei: destino brasileiro de oleiros barcelenses. Barcelos: Museu de Olaria, 1989.

DIÁRIO DE JABOTICABAL, 5/10/1938 a 8/2/1939.

EXPOSIÇÃO NACIONAL DE 1908 - RIO DE JANEIRO: Estado de São Paulo: Catálogo Geral Illustrado. 2. ed. Rio de Janeiro: s.n., 1908.

FILIPPINI, E. O núcleo e os empreendimentos industriais. Disponível em: <http://www.ecco. com.br/vita_mia/imigra18.asp>. Acesso em: 13/7/2003.

FREITAS,A.A. de. Tradições e reminiscências paulistanas. 2. ed. São Paulo: Livraria Martins, 1955.

GRANDE ENCICLOPÉDIA Portuguesa e Brasileira Lisboa: Editorial Enciclopédia Limitada, 1953.v. 11.

GUIA DOS DOCUMENTOS HISTÓRICOS na cidade de São Paulo: 1554-1954. São Paulo: Hucitec, 1998.

HOLANDA, S. B. de. Caminhos e fronteiras. 3. ed. São Paulo: Companhia das Letras, 1994.

HOYOS, R. Progreso de la filtración casera en América Latina. Água Latinoamérica. Disponível em: <http://www.agualatinoamerica.com/docs/PDF/1-2-02hoyos.pdf>. Acesso em: 6/4/2003.

LAPRI, R. O Estado de São Paulo e o centenário da Independência. São Paulo: s.n., [1922?].

LEMOS, C.A. C. Casa paulista: história das moradias anteriores ao ecletismo trazido pelo café. São Paulo: Edusp, 1999.

MANNING, E. Os Estados Unidos do Brasil: sua bistória, seu povo, comércio, indústrias e recursos. Rio de Janeiro: The South American Intelligence, 1919.

PEIXOTO,A. Elementos de hijiene. Rio de Janeiro: Francisco Alves \& Cia, 1913.

PENNA, B. Saneamento do Brasil. 2. ed. Rio de Janeiro: Jacintho Ribeiro dos Santos, 1923.

PILEGGI, A. Cerâmica no Brasil e no mundo. São Paulo: Livraria Martins, 1958.

RIBEIRO, M.A. R. História sem fim... Inventário da Saúde Pública: São Paulo - 1880-1930. São Paulo: Editora Unesp, 1993.

SÃO PAULO. Secretaria da Agricultura, Industria e Commercio do Estado de São Paulo. Directoria de Estatistica, Industria e Commercio; secção de Indústrias. Estatistica industrial do Estado de São Paulo, 1928-1937. 10 v. São Paulo: Garraux/Siqueira/Freire \& Cia, 1930/1939. 
Secretaria da Agricultura, Commercio e Obras Publicas do Estado de São Paulo. Boletim da Directoria de Industria e Commercio. São Paulo:Typ. Brazil de Rothschild \& Cia, 1921, 1922, $1923,1927$.

. Secretaria do Meio Ambiente. A água no olbar da bistória. São Paulo: A Secretaria, 1999.

TAUNAY, A. d'E. História da cidade de São Paulo no século XVIII (1735-1765). São Paulo: Divisão do Arquivo Histórico, 1949. v. 1, parte 2.

. História da cidade de São Paulo no século XVIII (1765-1801). São Paulo: Divisão do Arquivo Histórico, 1951.v. 2, parte 1.

. História colonial da cidade de São Paulo no século XIX (1801-1822). São Paulo: Divisão do Arquivo Histórico, 1956a. v. 3.

. História da cidade de São Paulo sob o Império (1822-1831). São Paulo: Divisão do Arquivo Histórico, 1956b. v. 4.

. História da cidade de São Paulo sob o Império (1842-1854). São Paulo: Divisão do Arquivo Histórico, 1977.v. 6.

UMA INDÚSTRIA JUNDIAIENSE de porcelana que honra o Parque Industrial Brasileiro Diário de São Paulo, São Paulo, p. 9, 9/9/1953.

Fontes Orais (entrevistas gravadas)

João Gonçalves Pito (imigrante português, historiador, ex-ceramista) - Jaboticabal, 8/1/2003 e 9-6-2003.

Victor Lamparelli Júnior (filho do fundador da Cerâmica Lamparelli) - Jaboticabal, 9/1/2003.

Mario Antonio De Stéfani (diretor da Cerâmica Stéfani) - Jaboticabal, 17/1/2003 e 3/2/2004.

Aparecido Paiva (Departamento de Produção da Cerâmica Stéfani) - Jaboticabal, 10/5/2003.

Rubens De Stéfani (fundador da Cerâmica Stéfani) - Jaboticabal, 10/5/2003, 24/7/2003 e $25 / 11 / 2003$.

Alexandre Alves Bessa (ex-gerente da Filtros Salus) - Jaboticabal, 4/6/2003.

Luiz Carlos Businaro Ferreira (gerente de Produção da Cerâmica Stéfani) - Jaboticabal, 7/6/2003, $14 / 6 / 2003,12 / 7 / 2003$ e 17/1/2004.

Artigo apresentado em 08/2004. Aprovado em 11 /2004. 